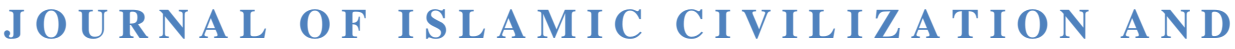
C U L T U R E ( J I C C )

Volume 3, Issue 1 (Jan-June, 2020)

ISSN (Print):2707-689X

ISSN (Online) 2707-6903

Issue: http://ahbabtrust.org/ojs/index.php/jicc/issue/view/8

URL: http://ahbabtrust.org/ojs/index.php/jicc/article/view/87/97

Article DOI: https://doi.org/10.46896/iicc.v3i01.87

Title

Analysis Of The Ideological Origins Of Armed Struggle In Islam

- Istamic Research Index Hit.

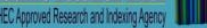

Author (s): $\quad$ Sami Ud Din, Dr. Dost

Muhammad

Received on: 29 June, 2019

Accepted on: 29 May, 2020

Published on: 25 June, 2020

Citation:

Sami Ud Din and Dr. Dost Muhammad, "Construction: Analysis Of The Ideological Origins Of Armed Struggle In Islam," JICC: 3 no, 1 (2020): 111-135

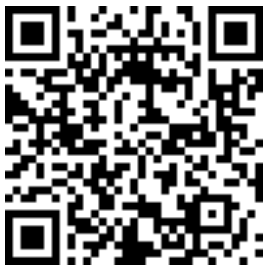

BE: HTIRNATIONAL

scientific Indexing
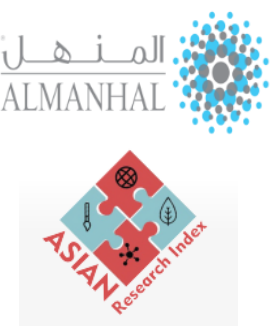

Crossref 


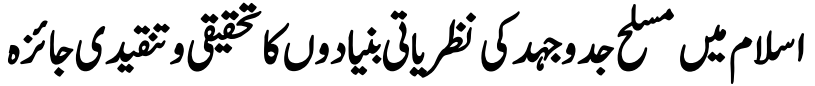

\section{ANALYSIS OF THE IDEOLOGICAL ORIGINS OF ARMED STRUGGLE IN ISLAM}

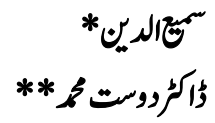

\section{Abstract}

Armed struggle is an issue of life-and-death judgments and that's why it needs solid justification from ethical and religious principles. Defending human life and preserving the society from anarchy, disintegration and destruction sometimes waging armed struggle become necessary and a group of people or nation is compelled to do so. Now one of the important aspects in this regard is, in which circumstances the nation is allowed for an armed struggle. All of the major world religions provide guidelines in this domain from strong militancy to absolute pacifism and just war theory. Islam too acknowledges the right of defense and preserving life to human beings. This paper seeks to map out the ideological approaches to armed struggle in Islam. The important scriptures from the holy Quran, Narrations of the holy prophet are briefly introduced and the relevant verses are extracted and summarized in the light of exegesis.

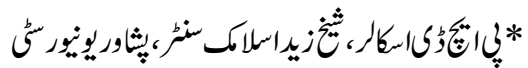

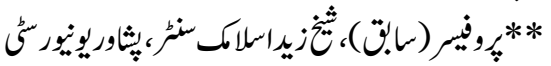




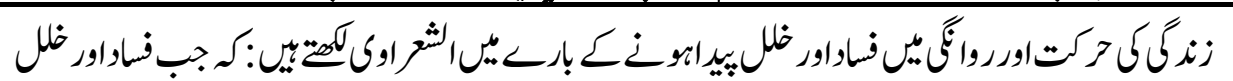

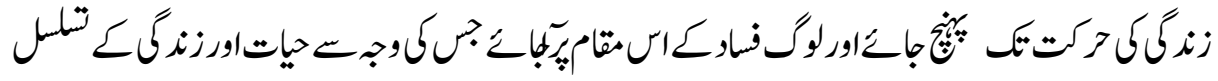

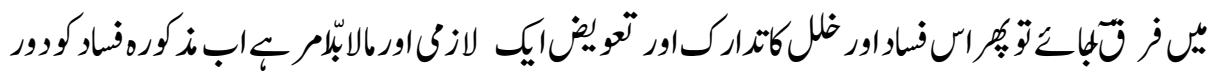

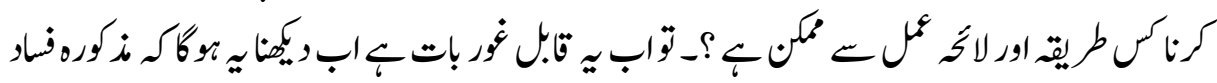

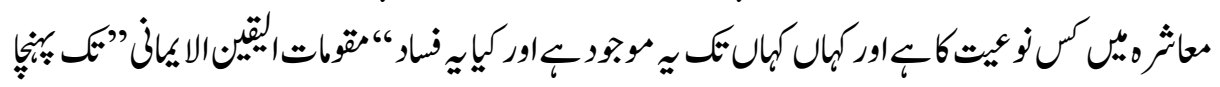

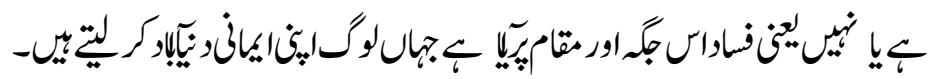

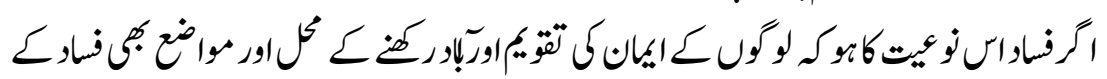

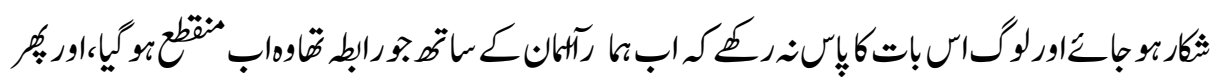

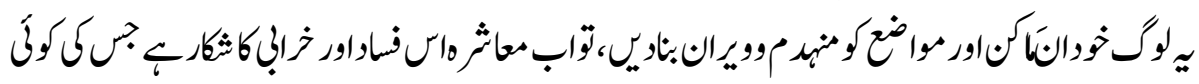

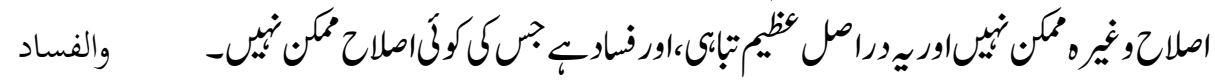

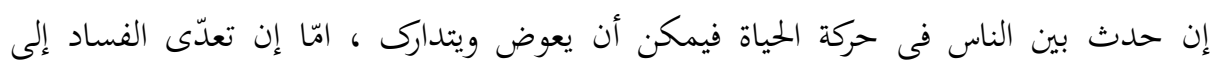

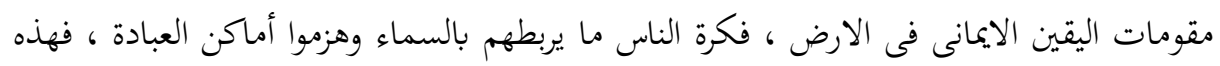

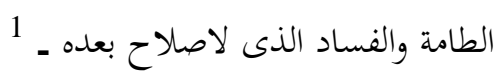

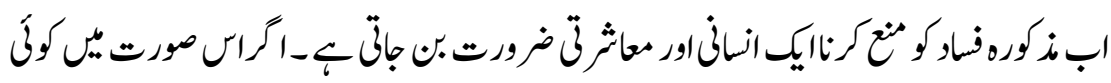

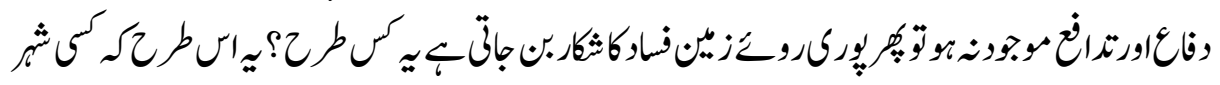

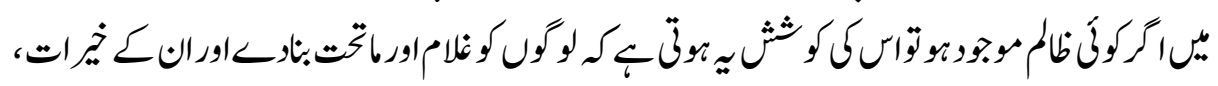

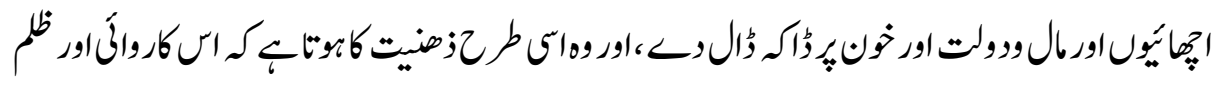

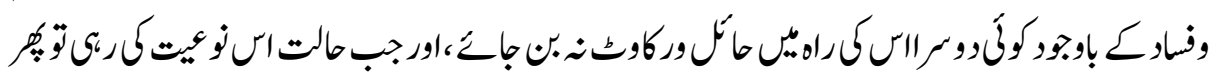

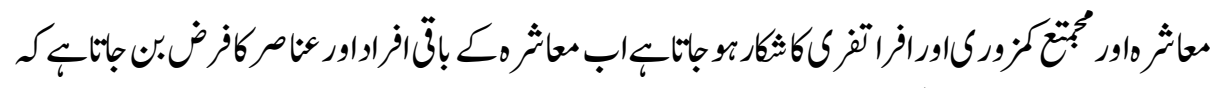

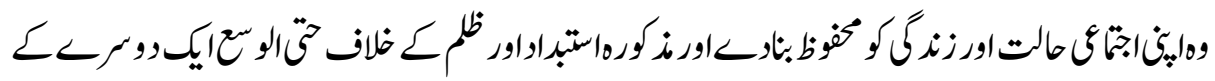

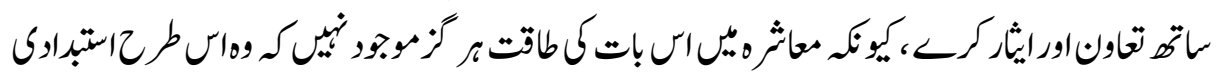

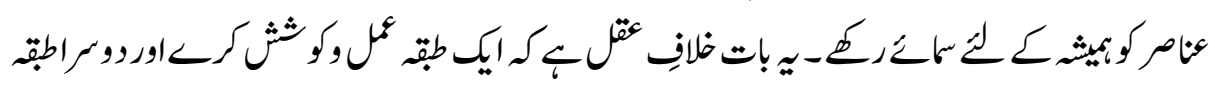

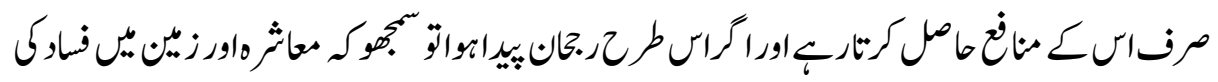

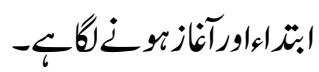
"وتفسر الأرض حين ينعدم هذا التدافع ، كيف؟ هب أن ظالماً مستبدافى بلد ما يستعبد 


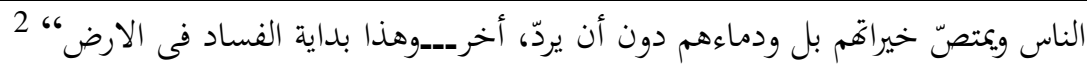

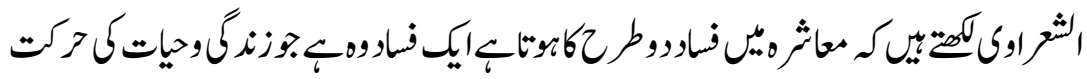

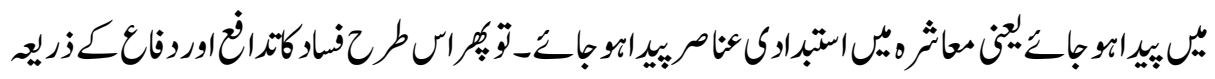

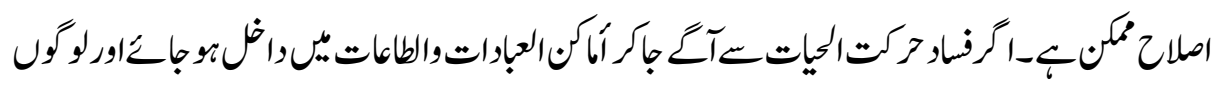

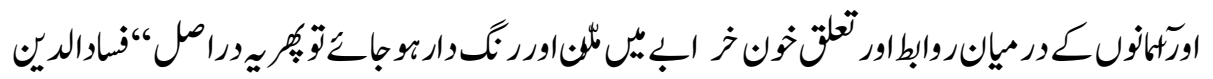

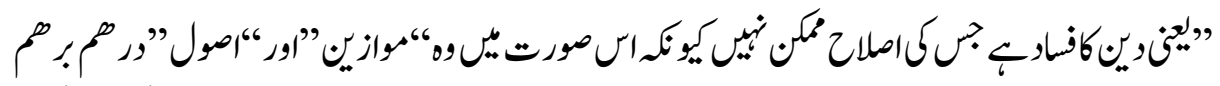

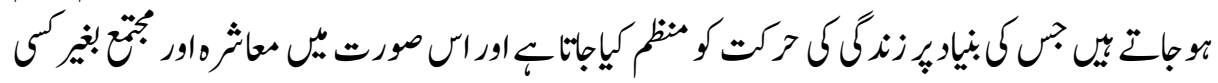

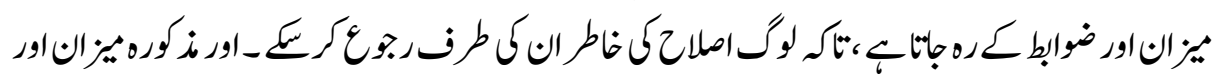

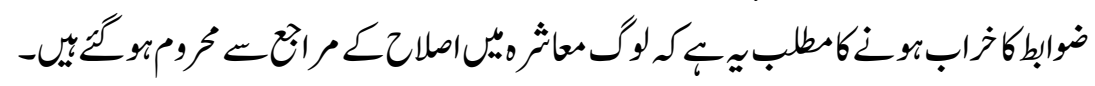

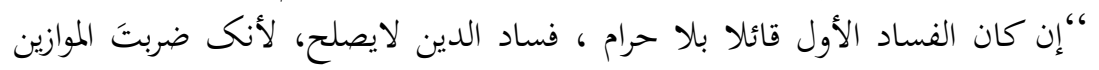

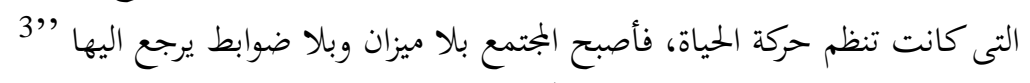

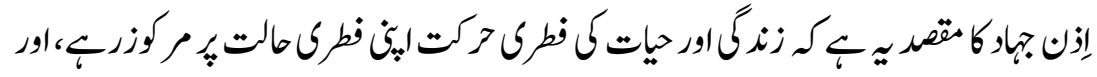

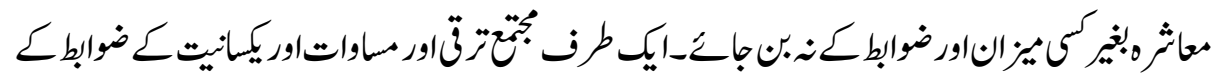

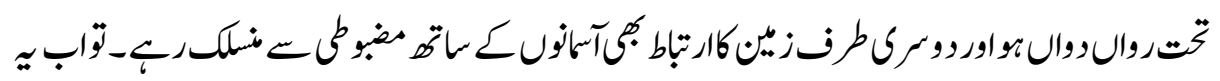

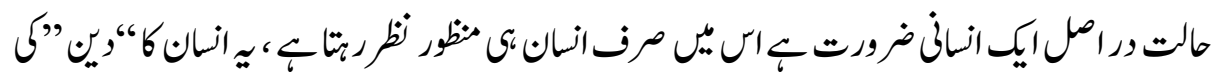

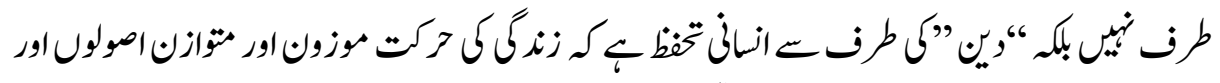

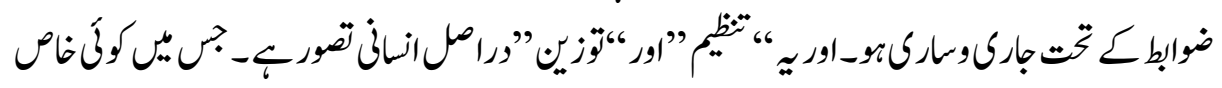

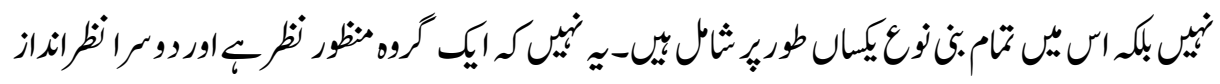

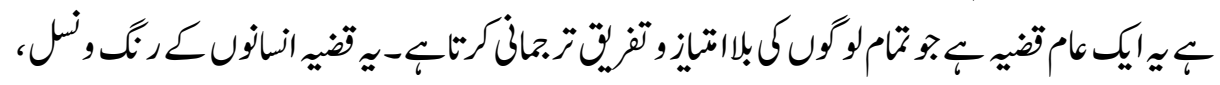

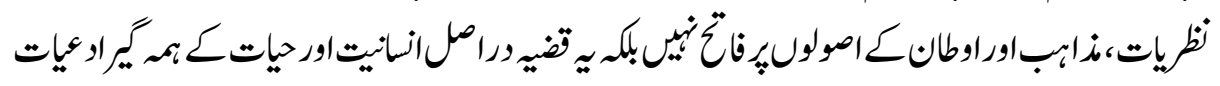

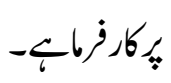

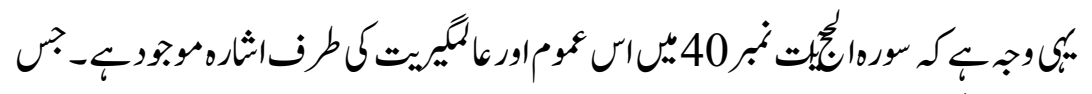

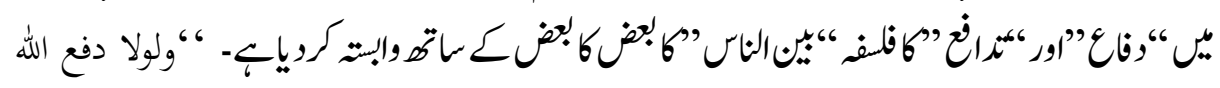

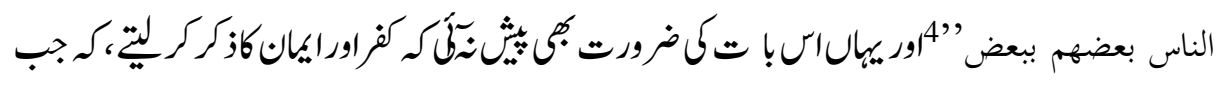

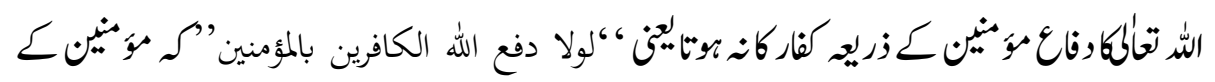




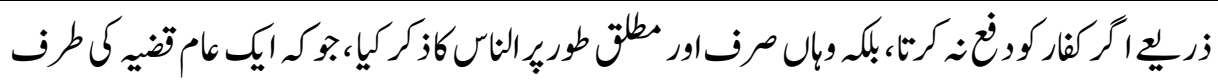

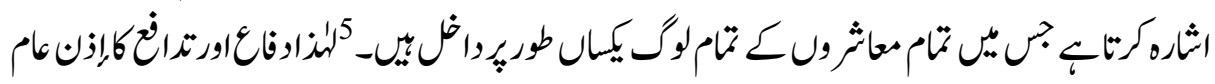

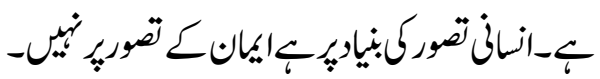

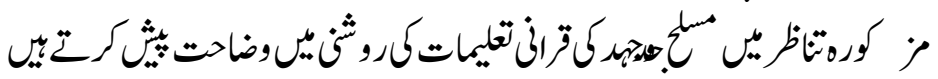

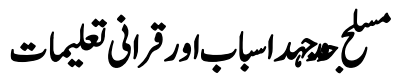

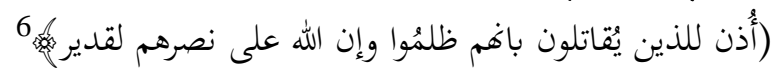

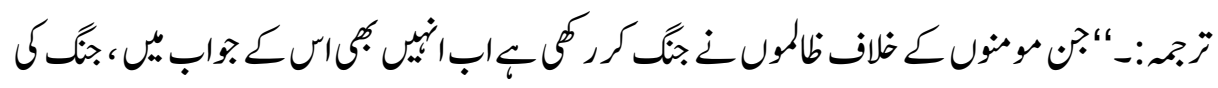

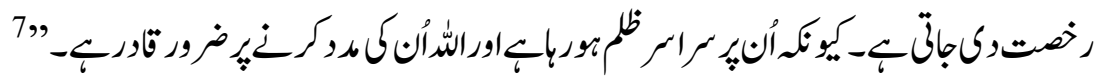

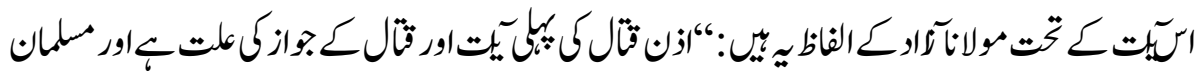

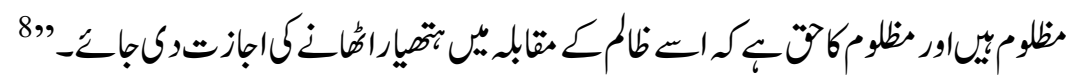

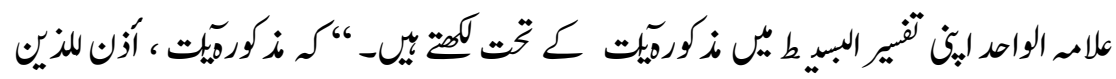

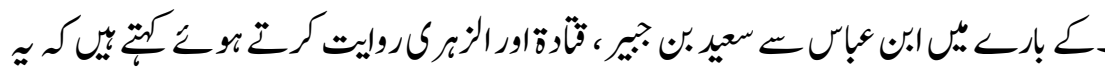

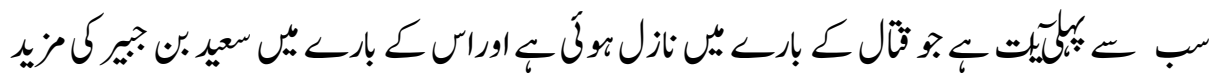

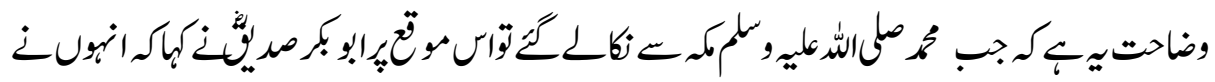

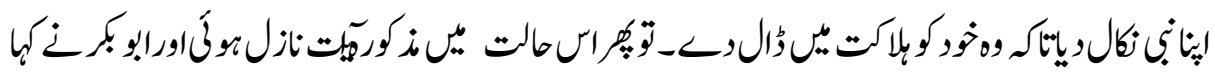

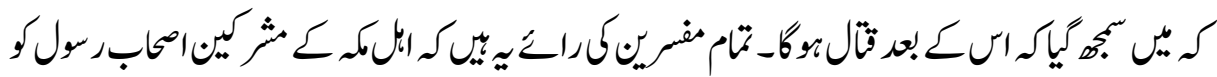

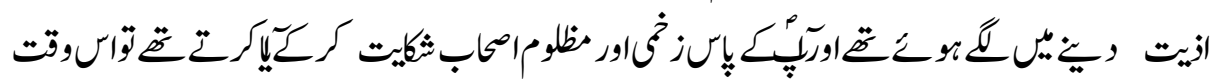

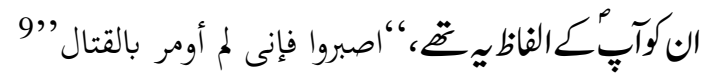

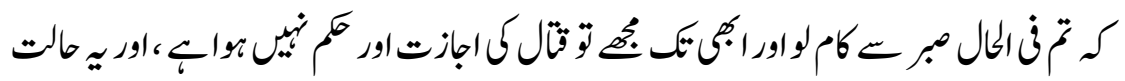

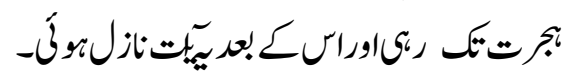

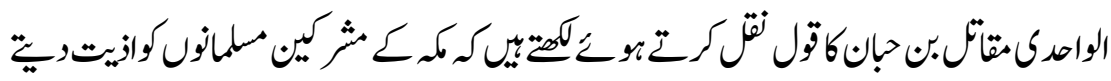

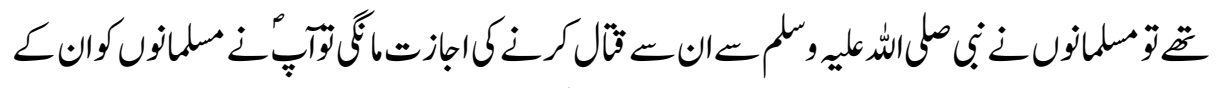

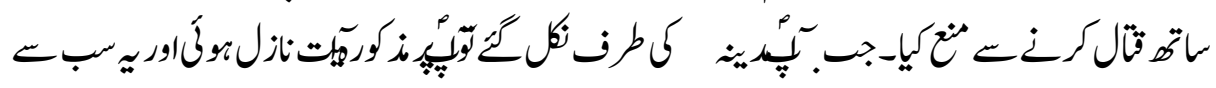

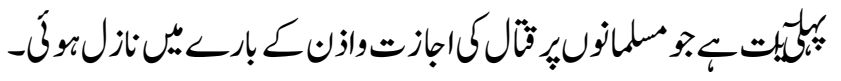
قال مقاتل بن حبان ان مشركى مكة كانوا يؤذون المسلمين بمكة ، فاستأذنوا النبى صلى لى لى 


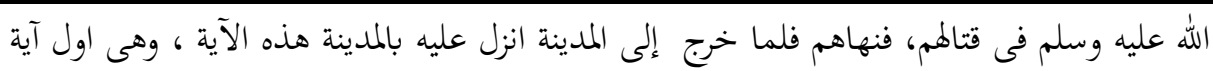
نزلت عليهم فى القتال - 10

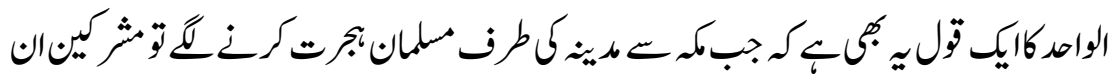

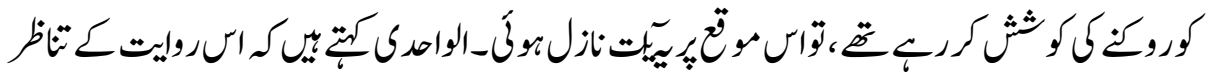

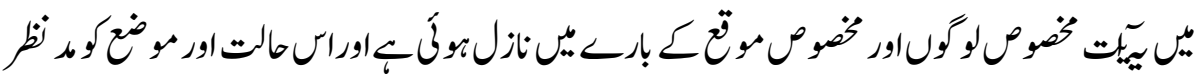

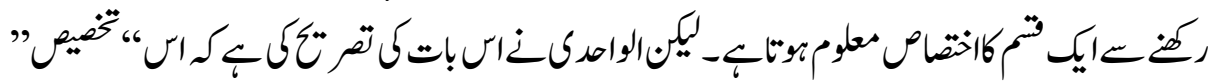

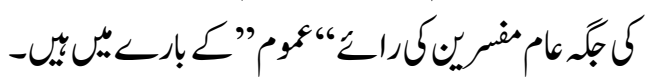

وعلئ هذا القول الآية نازلة فى قوم مخصوصين بأيمافم والقول الأول عليه أهل التفسير 11

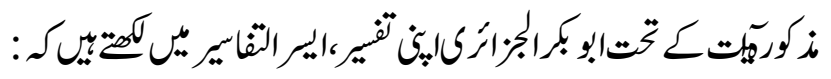

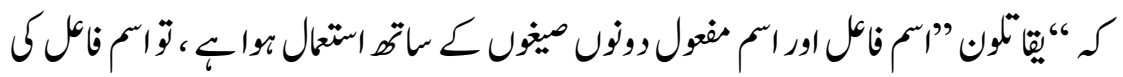

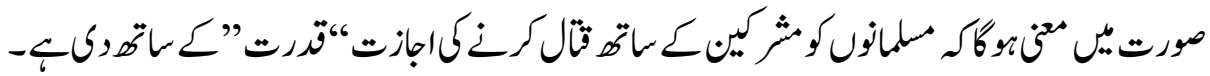

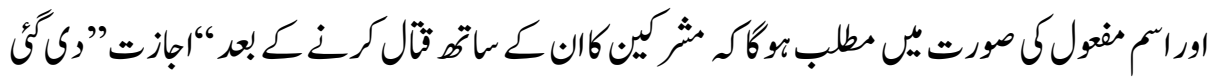

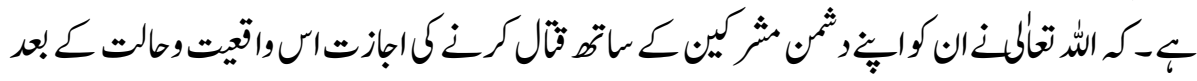

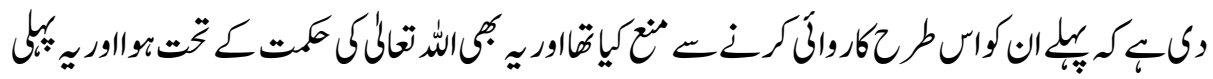

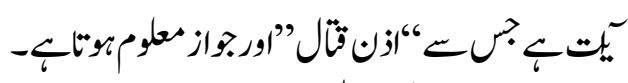

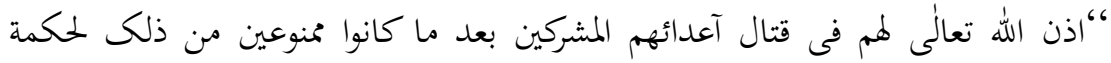

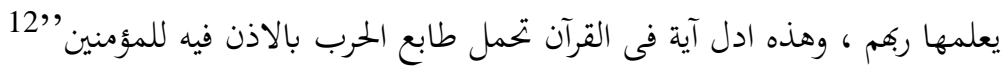

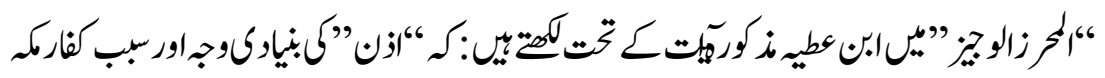

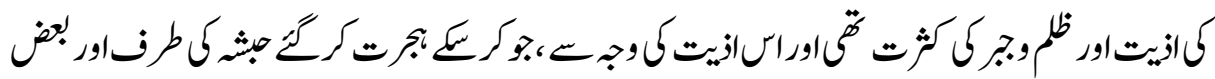

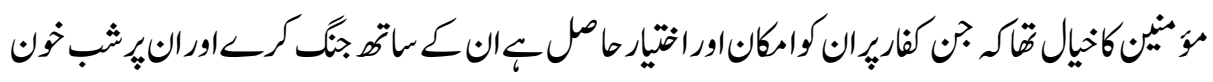

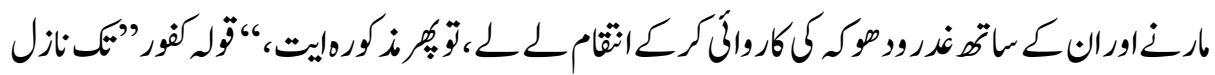

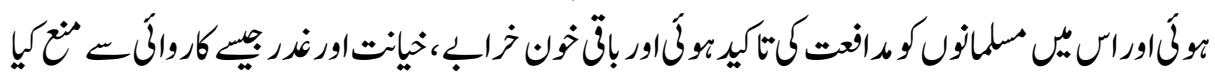

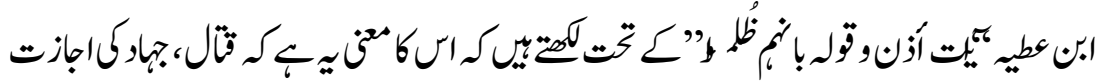

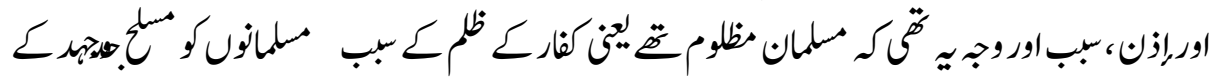




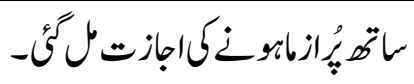

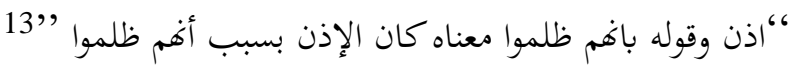

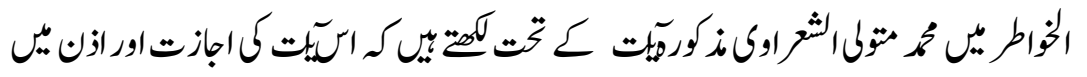

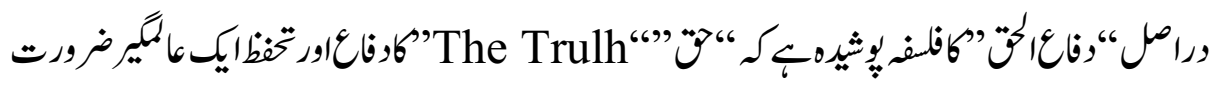

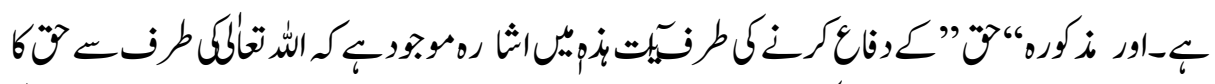

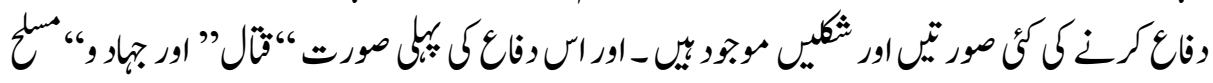

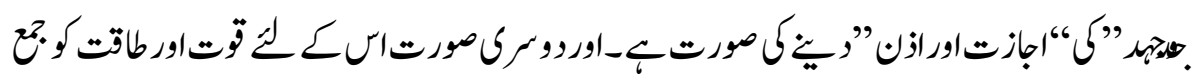

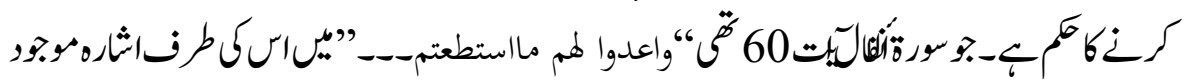

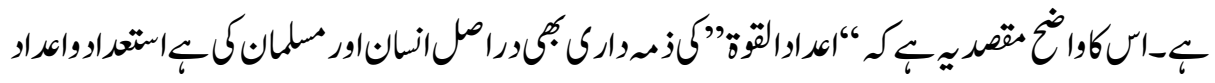

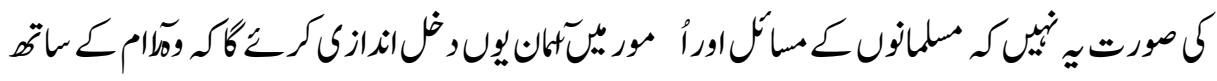

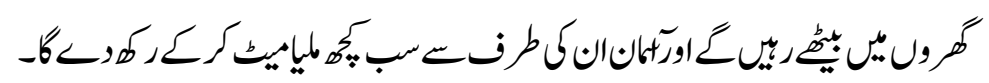

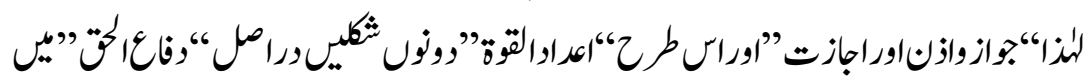

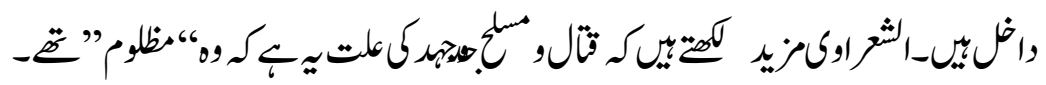

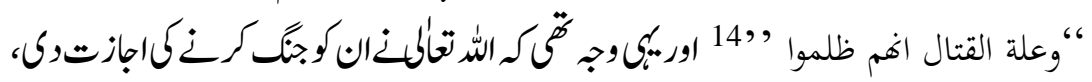

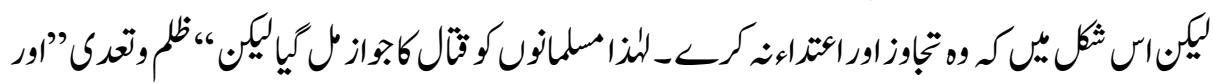

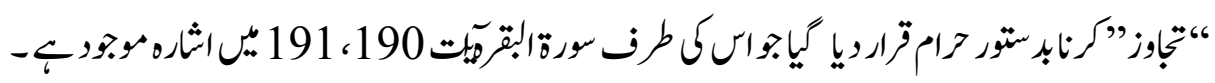

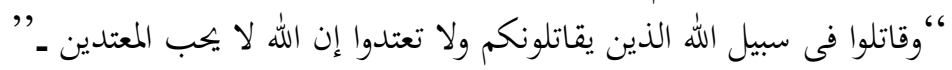

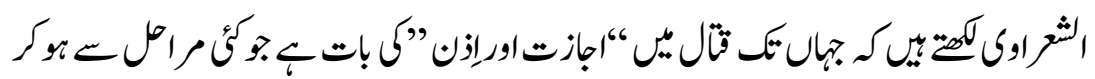

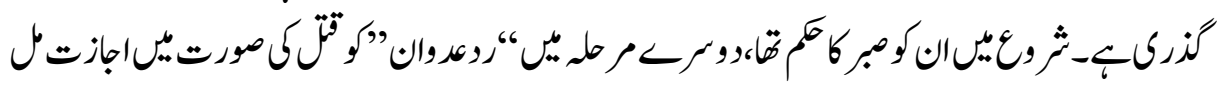

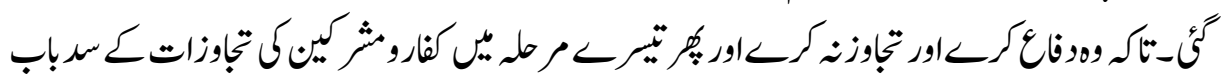

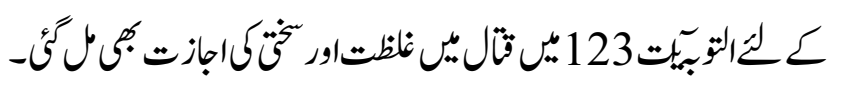

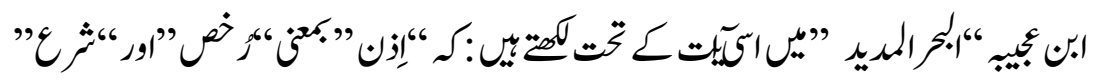

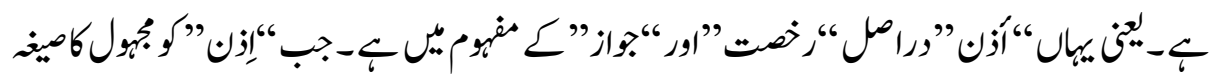

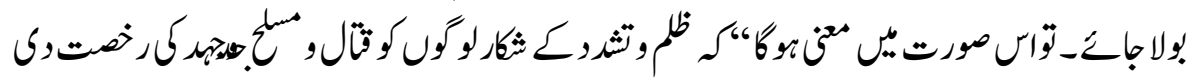

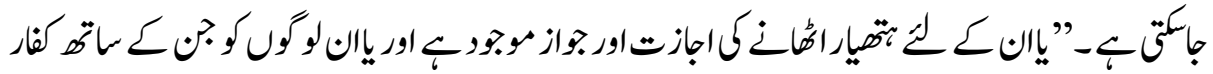




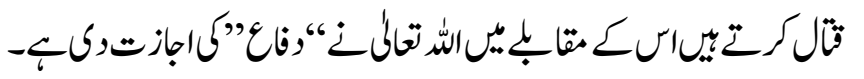

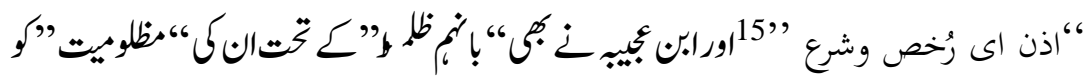

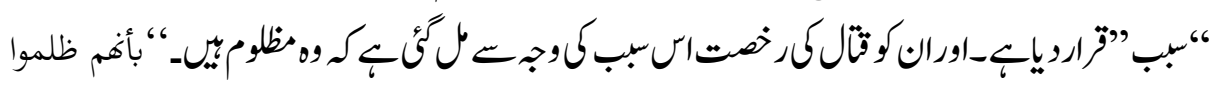

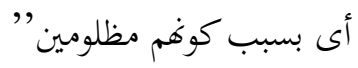

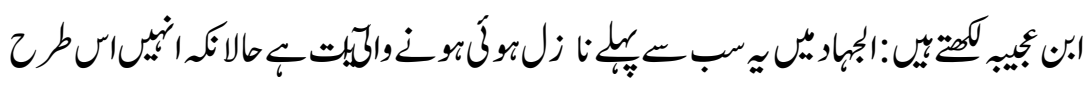

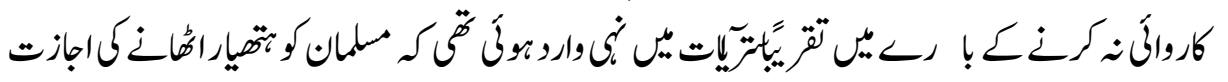

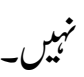

وهى اوّل آية نزلت فى الجهاد ، بعد ما فهى عنه فى نيف وسبعين آية 16

(2) مظلوميتكاسب!)(التوحير)

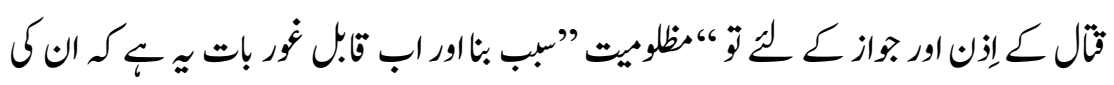

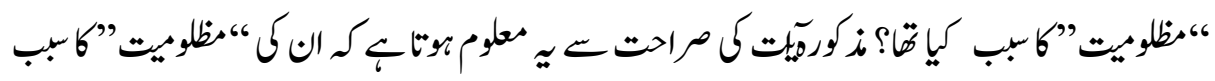

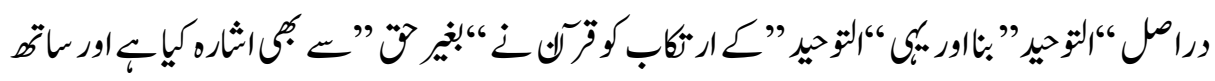

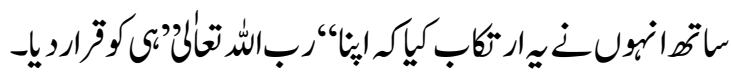

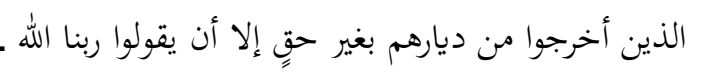

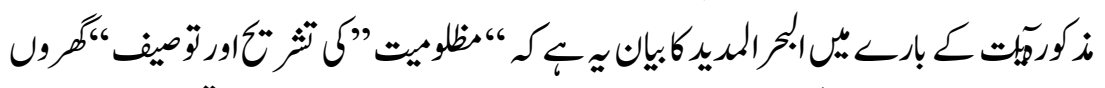

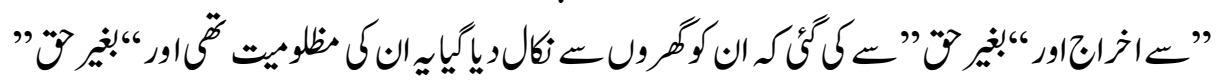

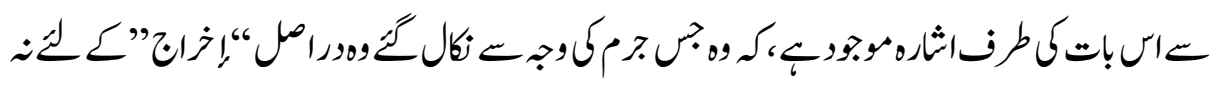

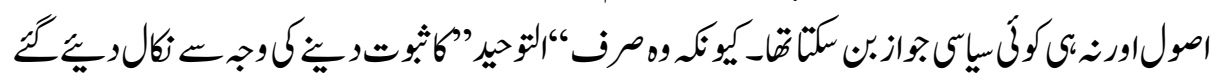

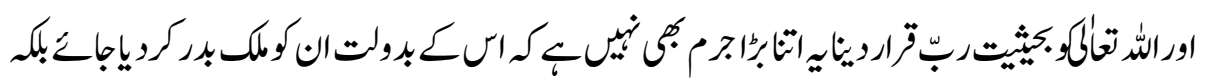

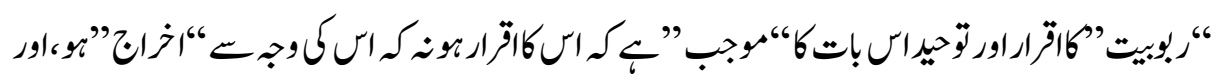

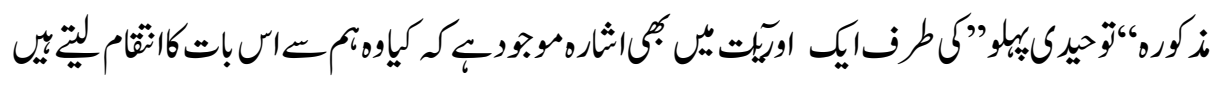

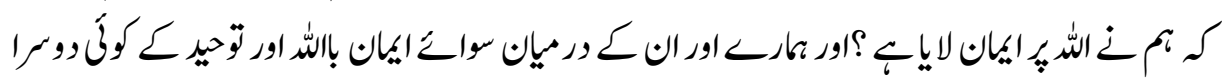

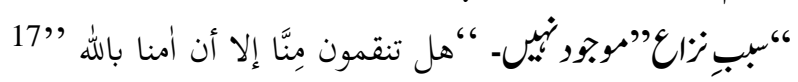

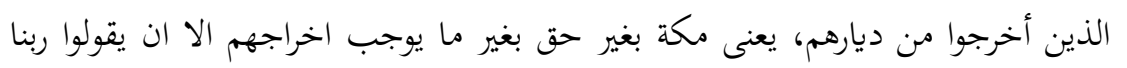
الله أى بغير موجب سوى التوحيد 18 


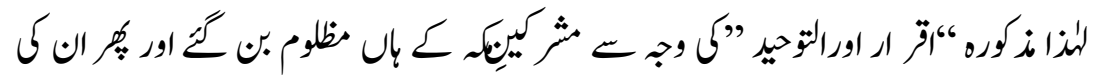

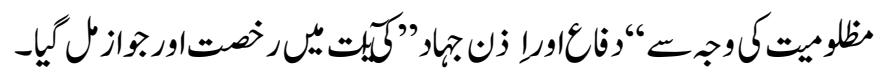

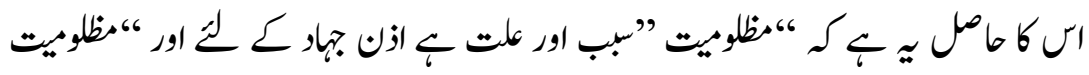

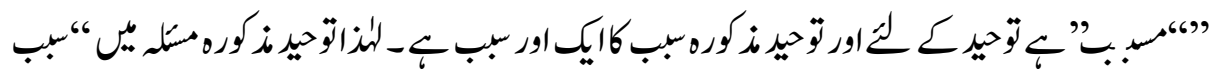

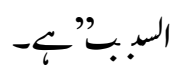

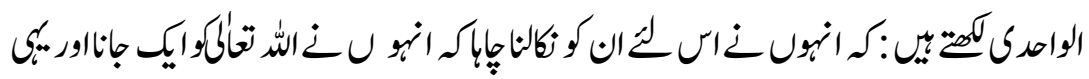

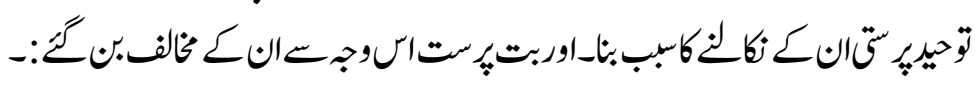

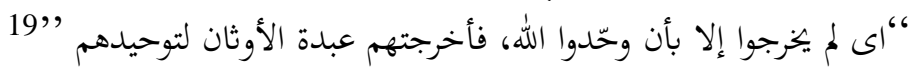

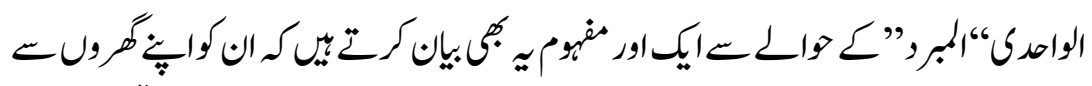

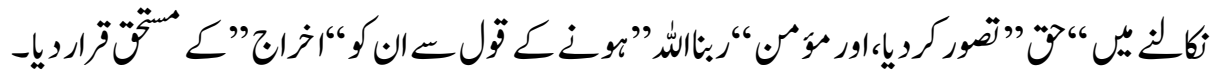

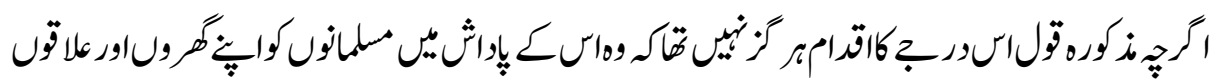

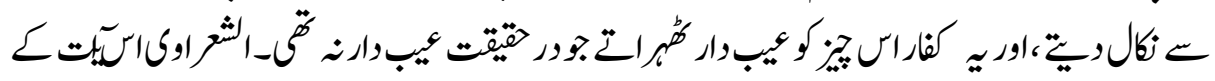

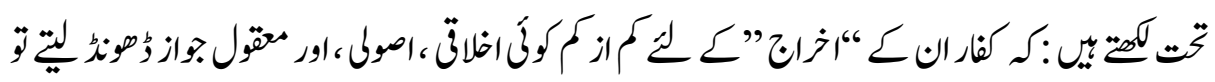

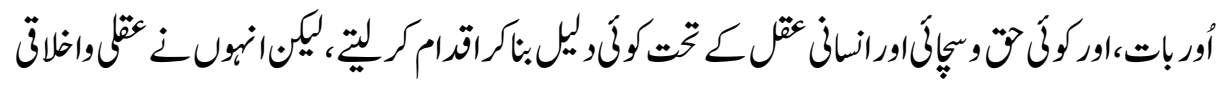

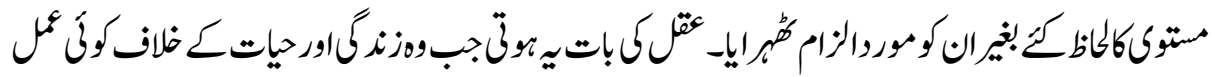

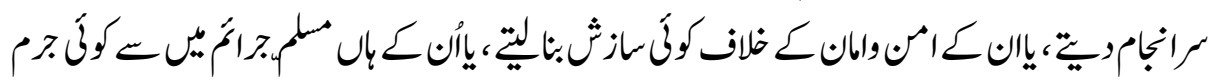

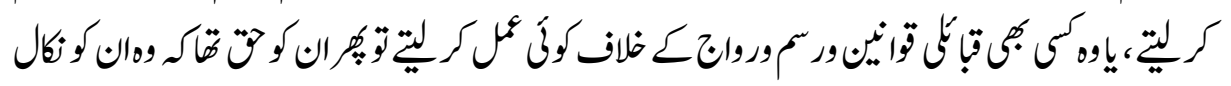

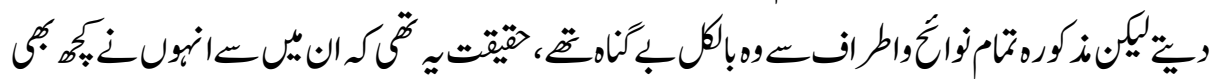

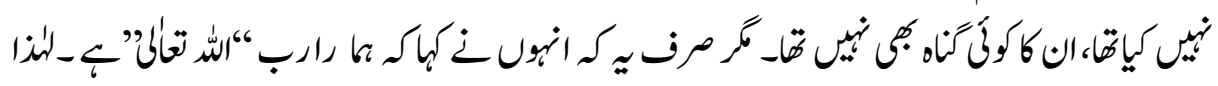

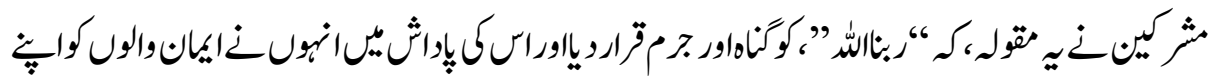

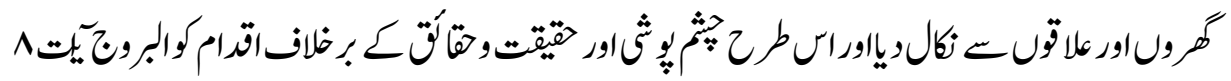

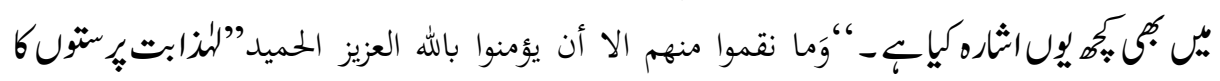

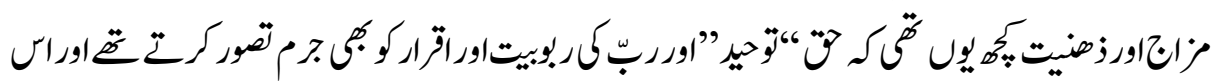

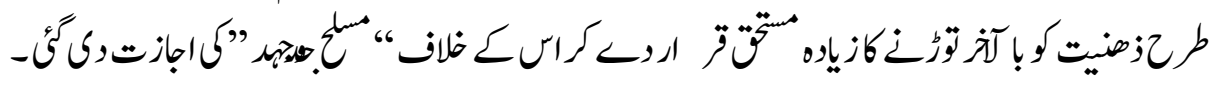

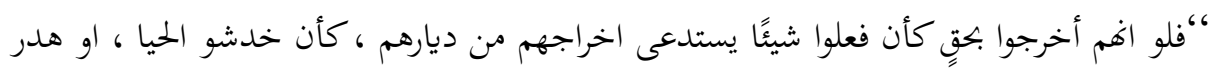




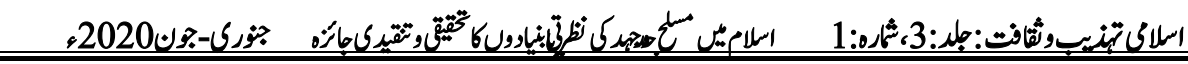

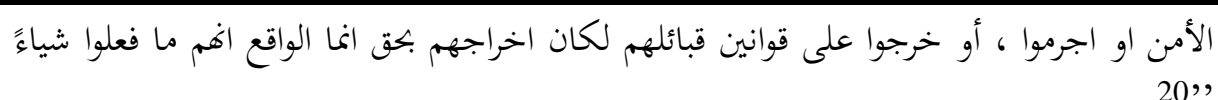

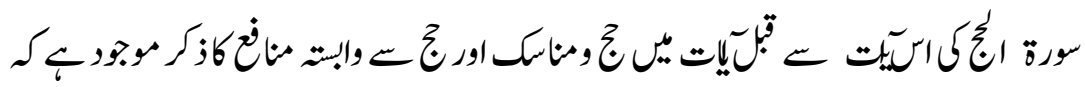

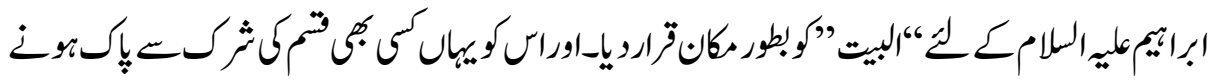

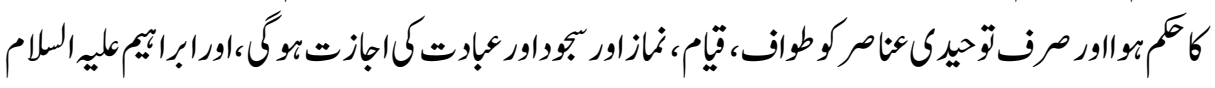

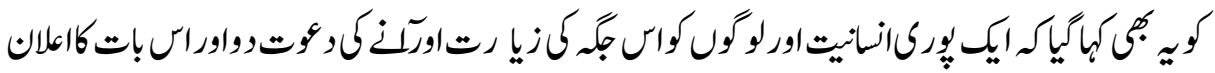

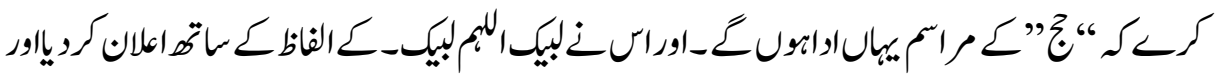

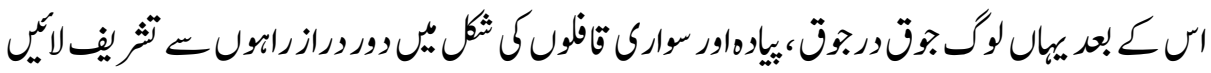

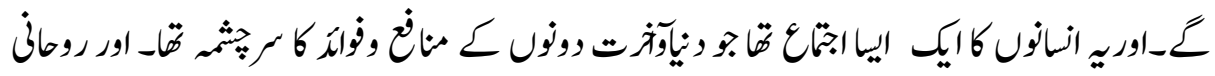

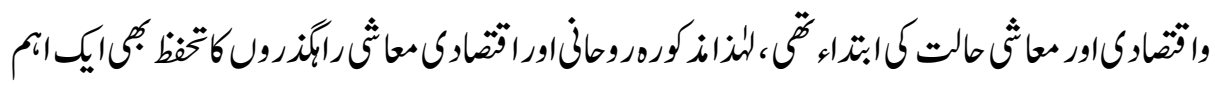

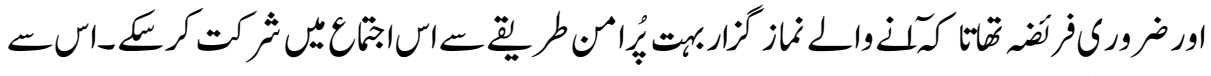

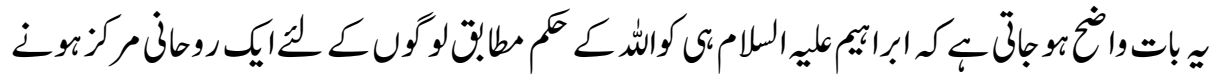

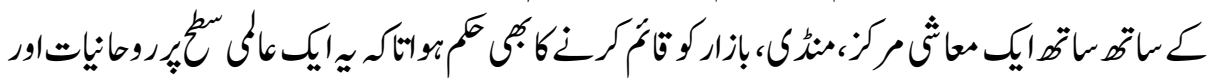

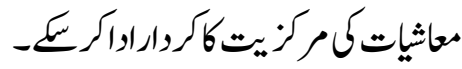

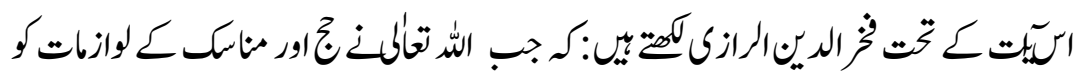

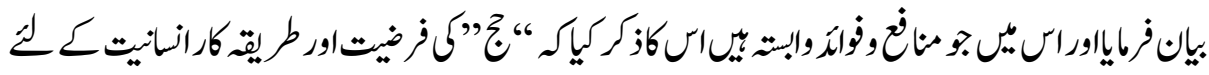

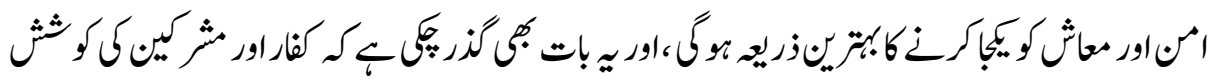

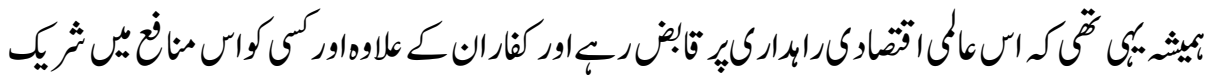

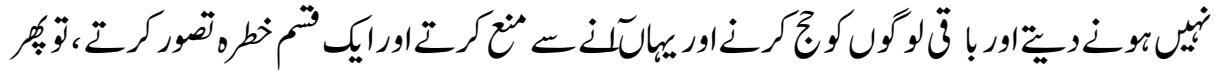

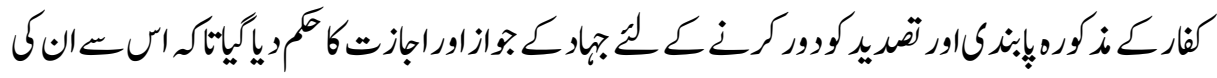

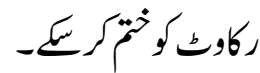

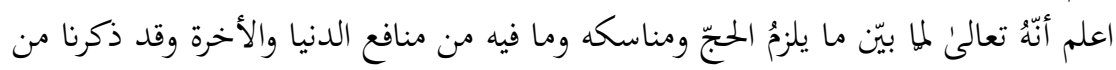

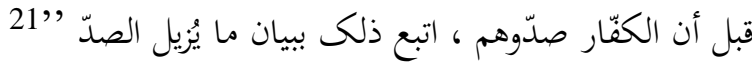

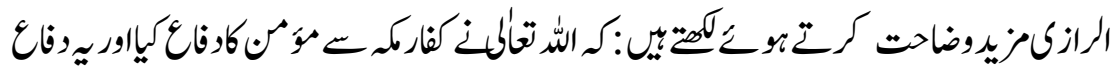

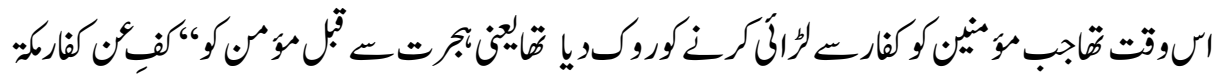

119 


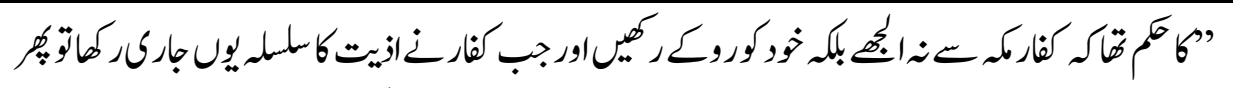

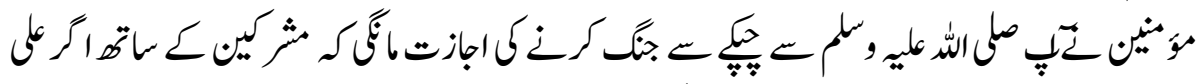

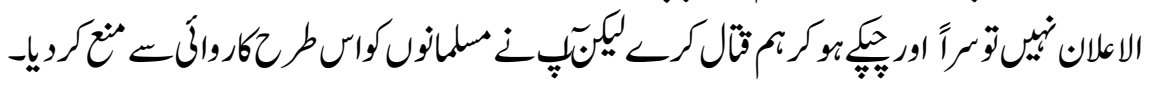

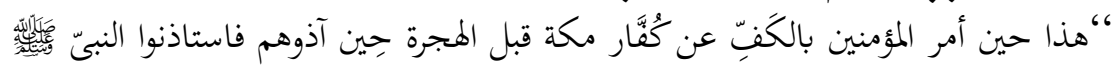

$$
\text { فى قتلهم سراً فنهاهم " } 22
$$

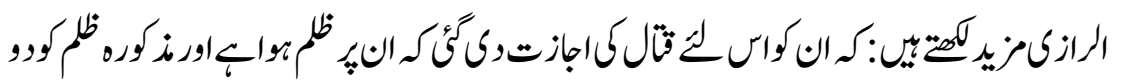

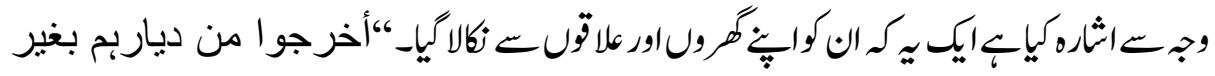

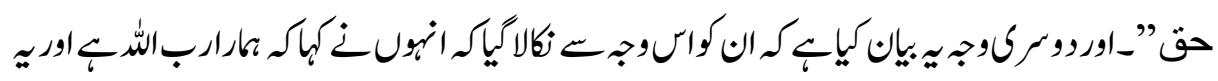

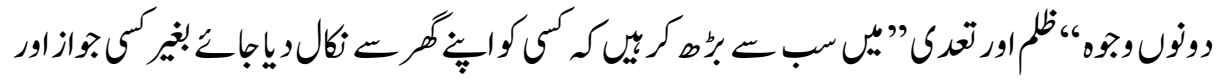

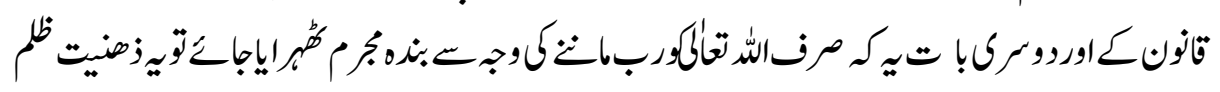
اورجبركارفتز بـ-"والثانى افم أخرجوهم بسبب اهم قالوا ربنالله وكل واحد من الوجهين عظيم فى الظلم"

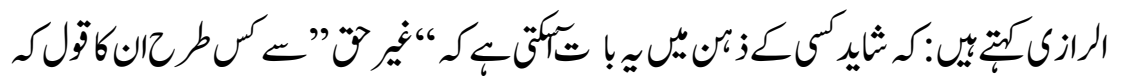

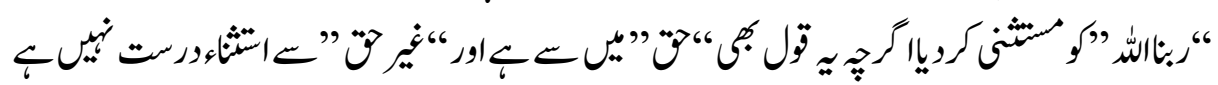

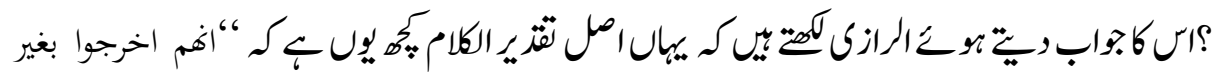

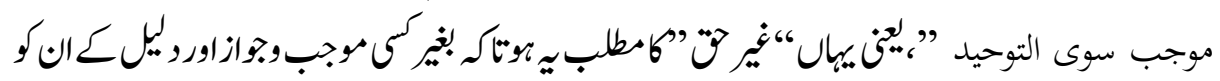

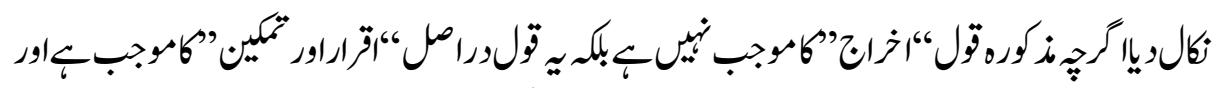

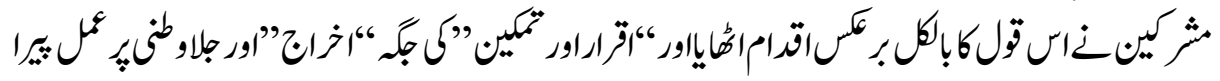

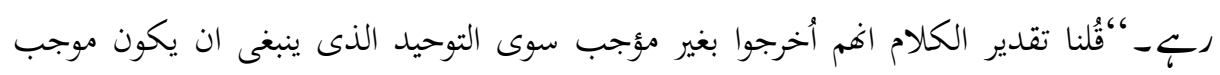

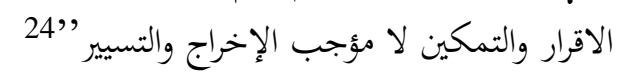

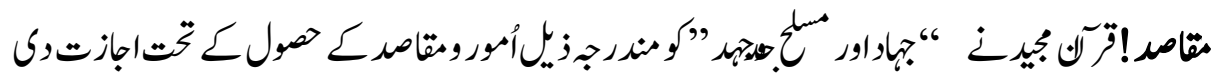
$-\frac{c}{6}$

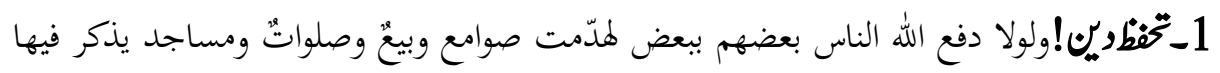
اسم الله كثير|25

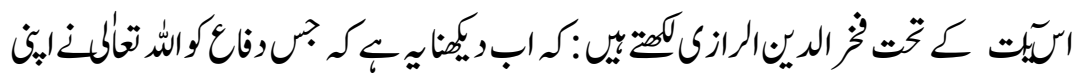




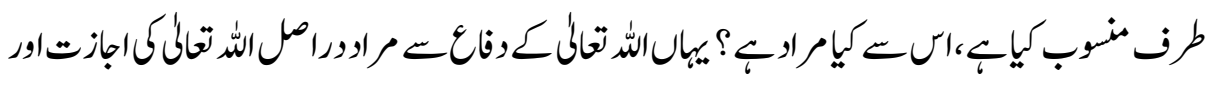

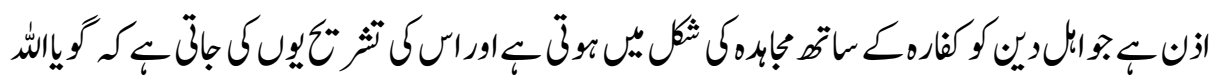

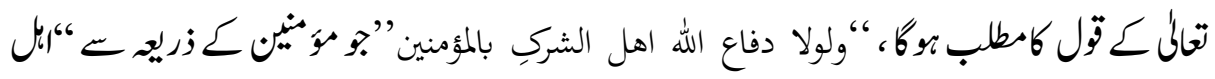

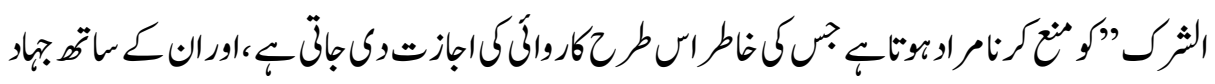

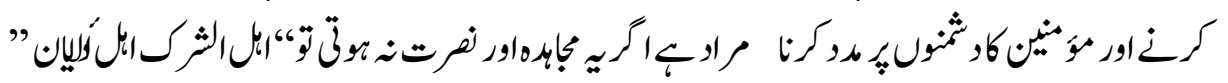

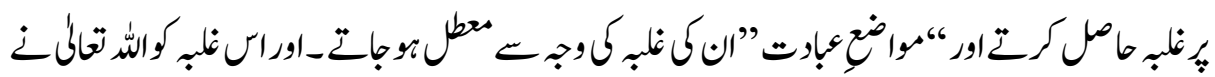

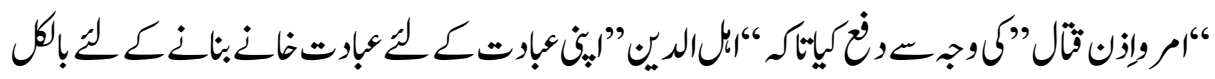

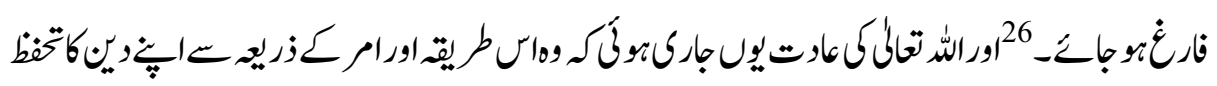

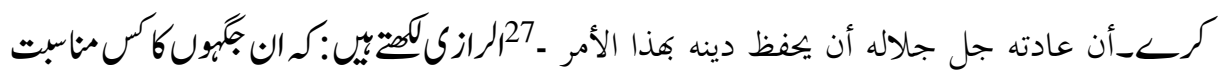

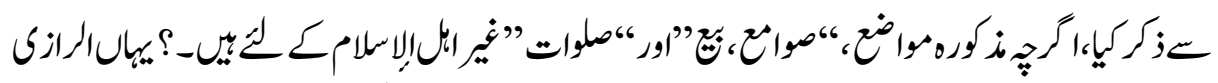

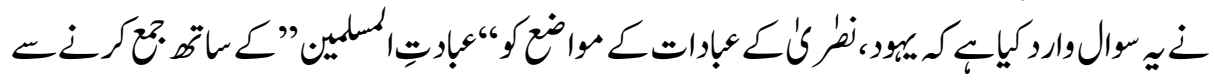

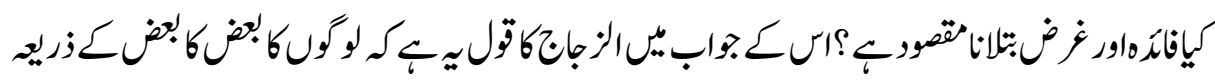

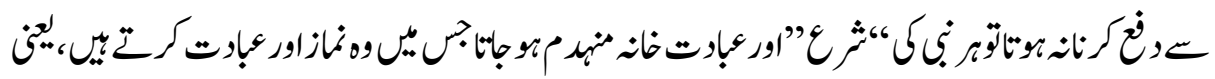

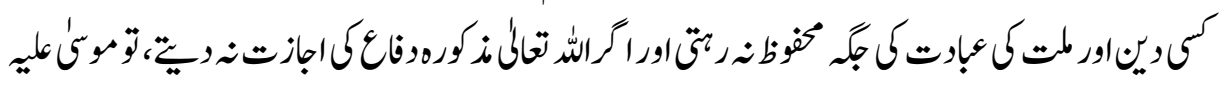

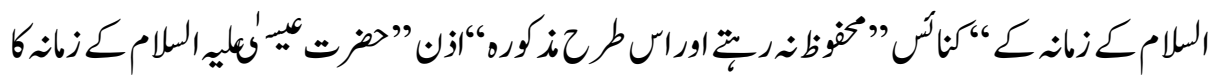

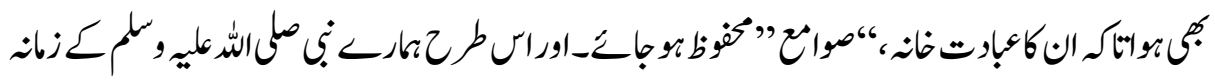

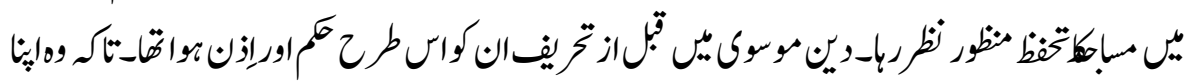
وفاع

“فلولا ذلك الدفع لمدم فى زمن موسئ الكنسائس التى كانوا يكلمون فيها فى شرعه ،

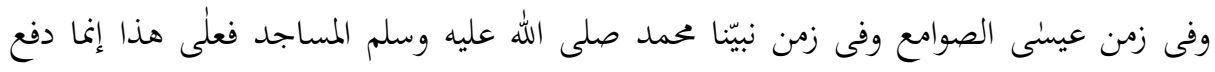

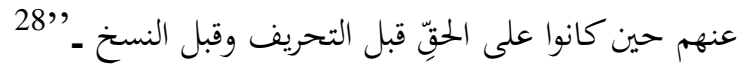

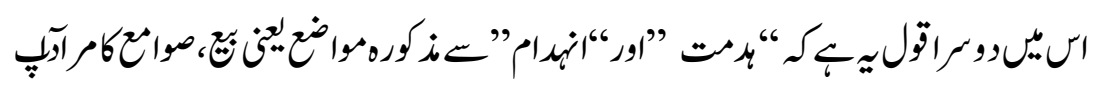

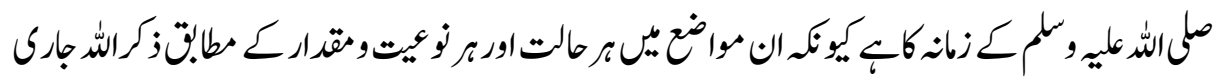

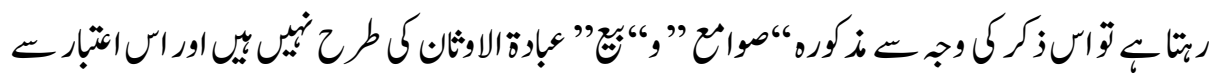

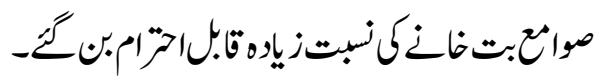




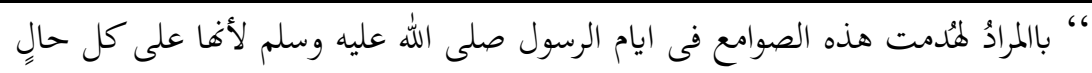

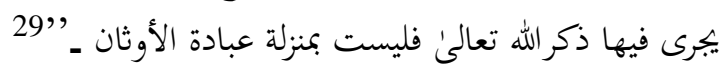

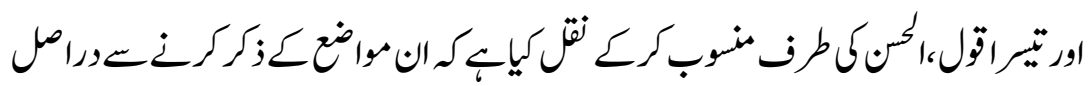

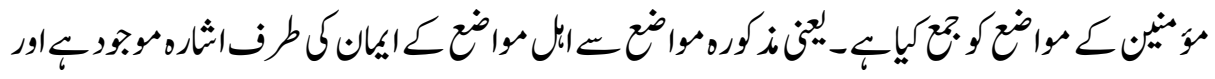

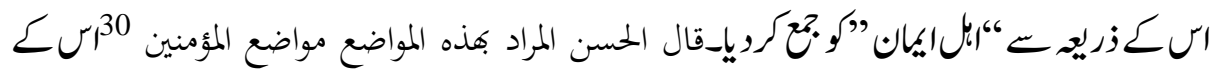

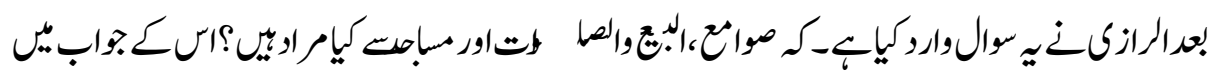

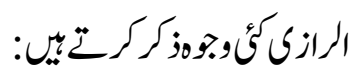

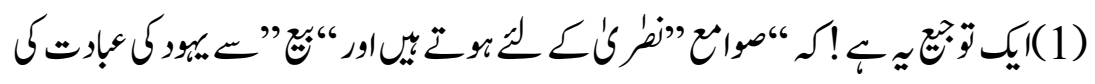

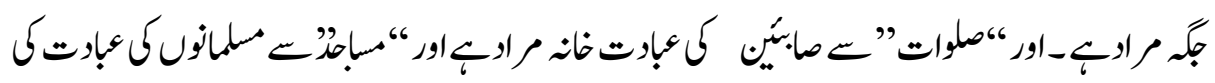

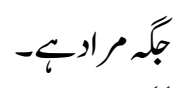

“'الصوامع للنصرى ، والبيع لليهود، والصلوات للصابئين والمساجد للمسلمين ـ"

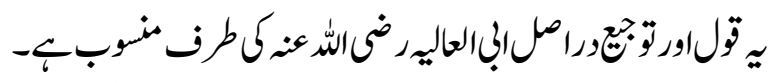

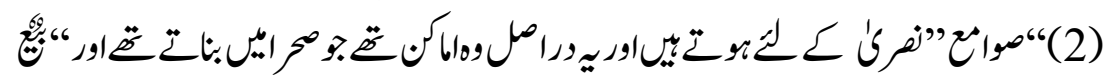

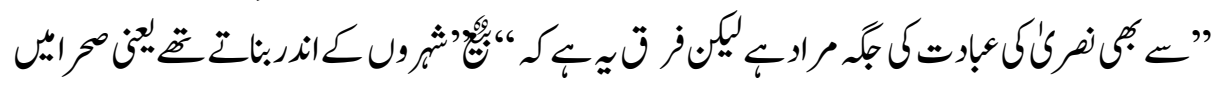

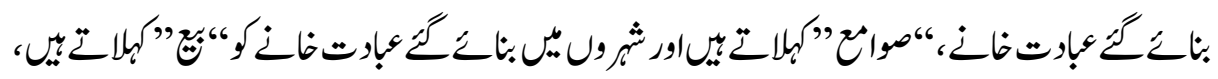

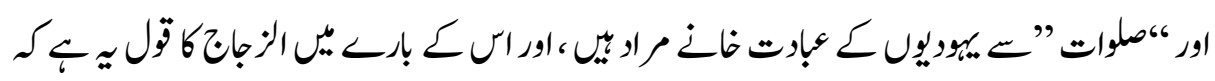

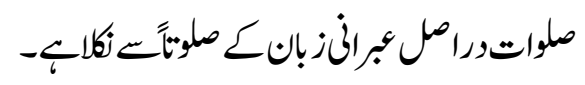

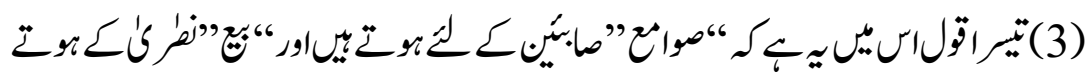

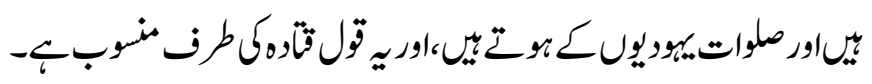

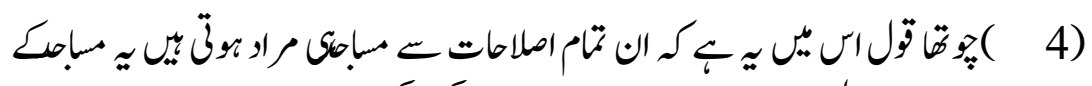

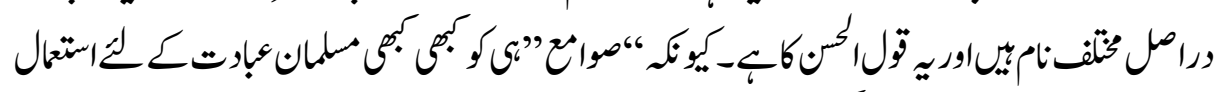

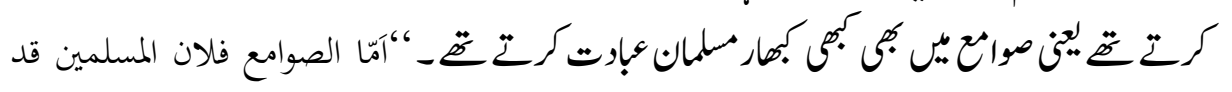

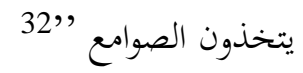

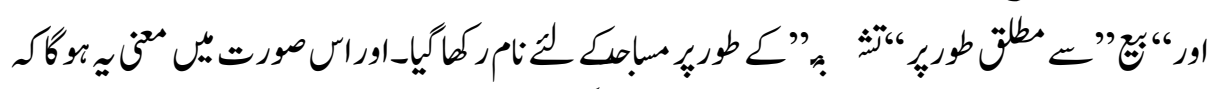

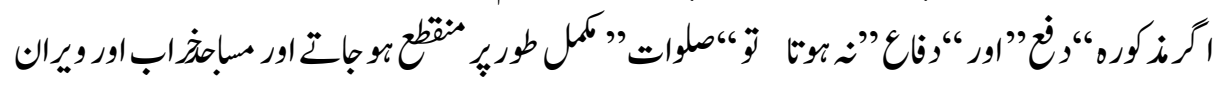




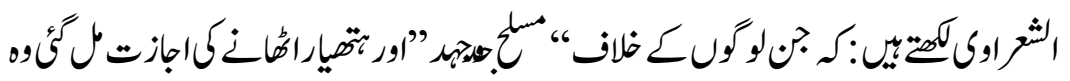

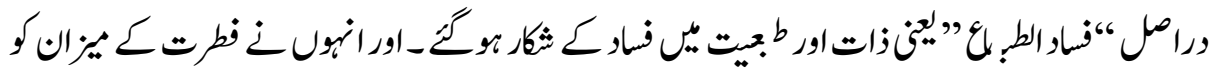

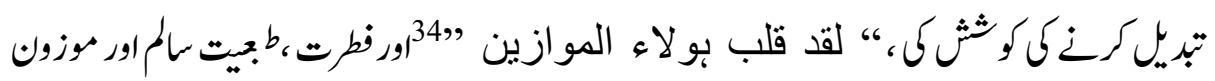

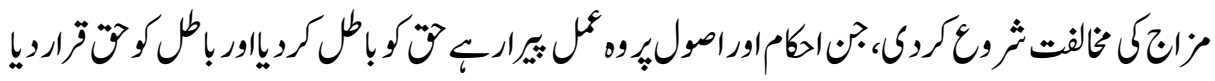

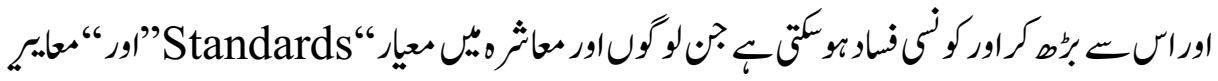

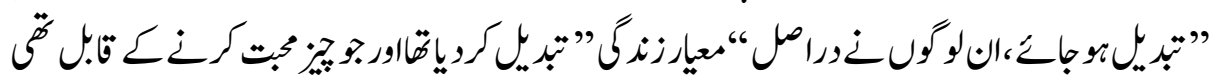

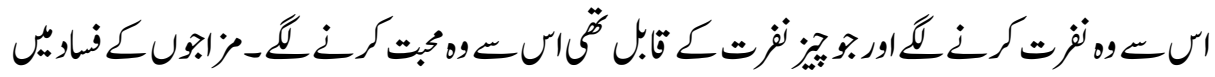

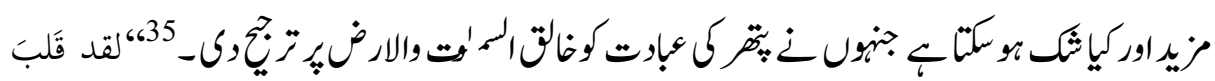

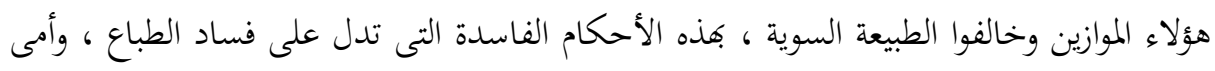

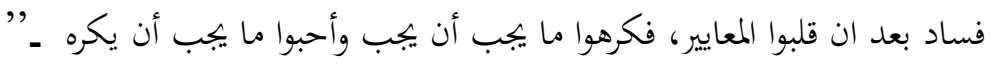

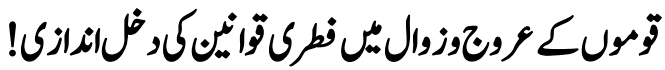

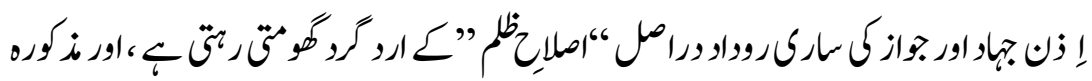

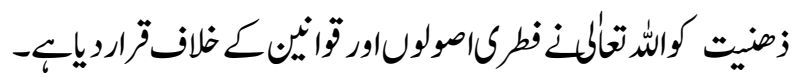

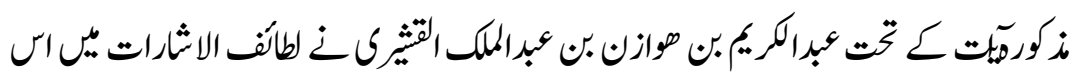

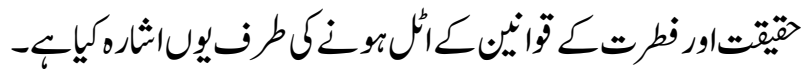

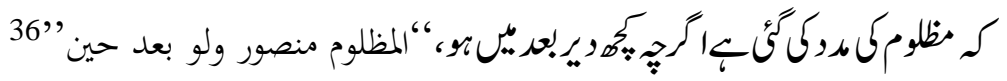

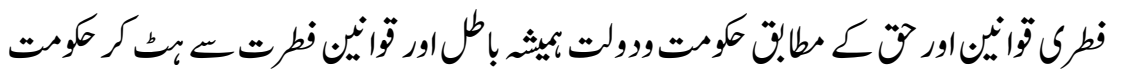

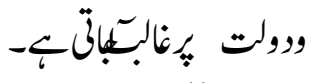

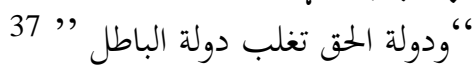

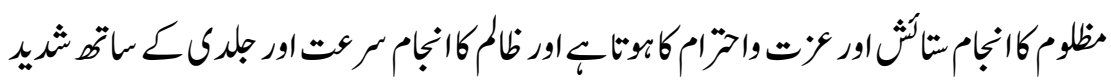

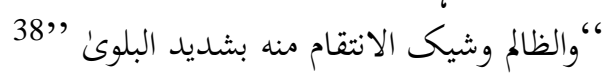

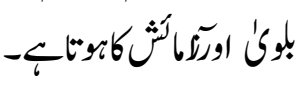

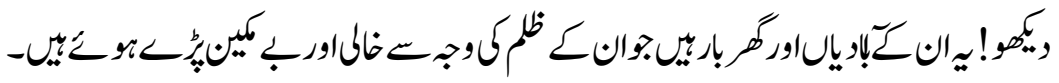

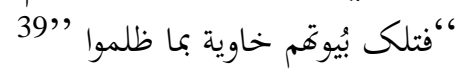




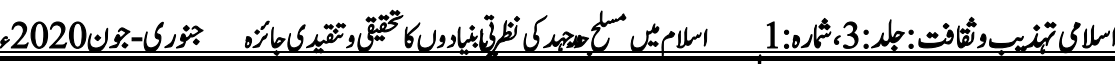

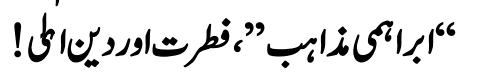

والتين والزيتون وطور سينين وهذا البلد الأمين لقد خلقنا الانسان فى أحسن تقويم 40

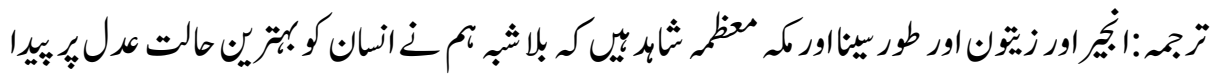

كيإ- 41

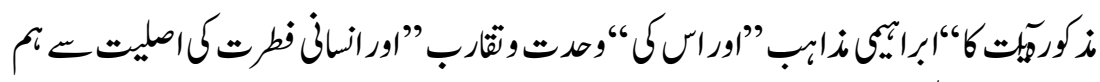

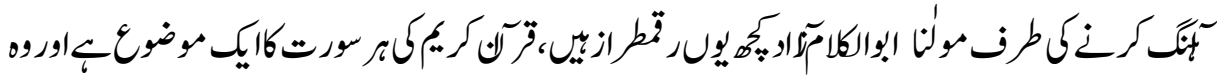

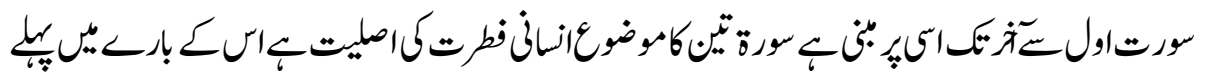

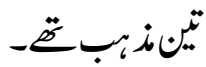

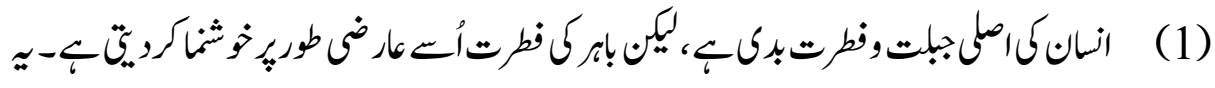

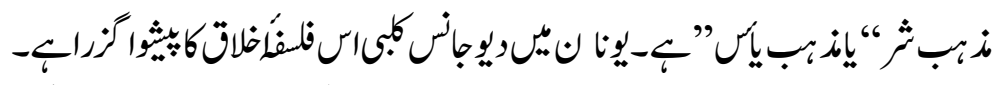

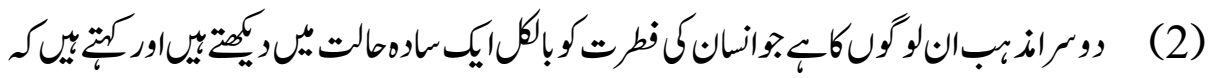

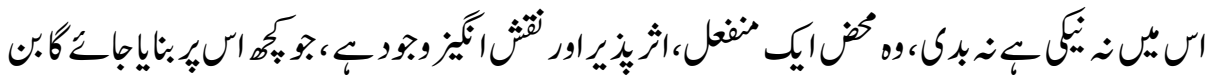

ج

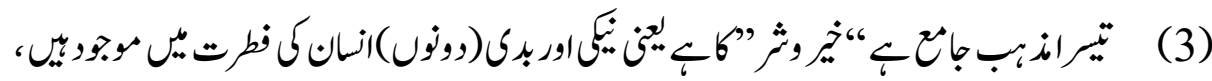

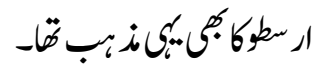

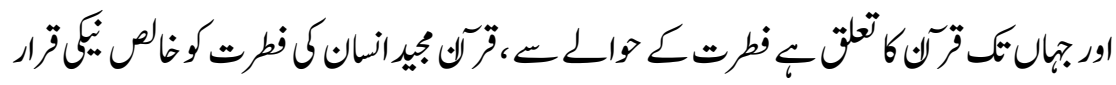

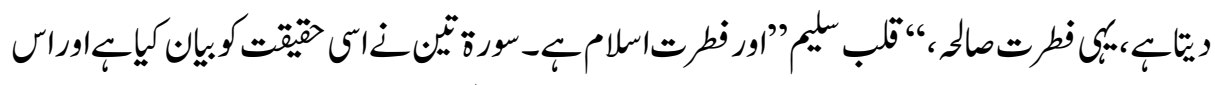

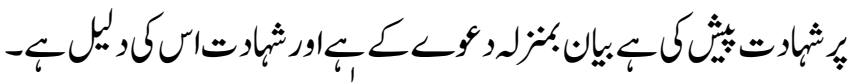

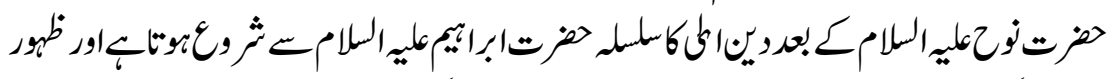

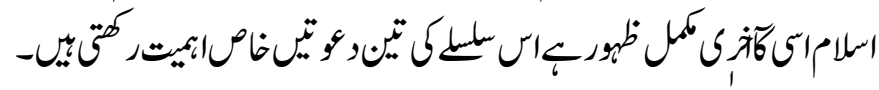

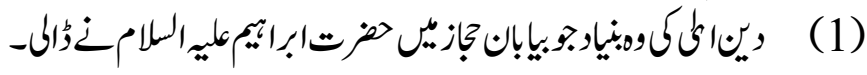

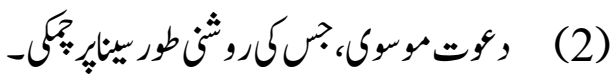

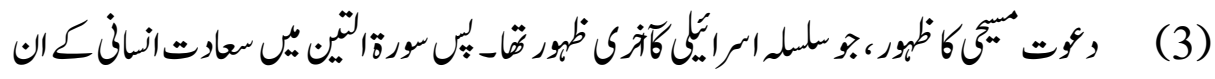

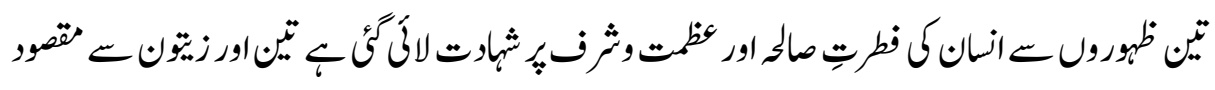

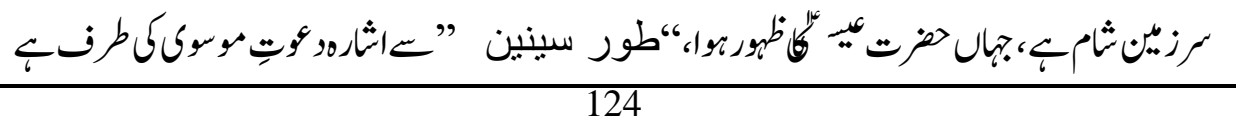




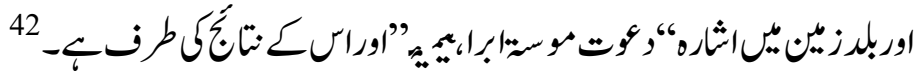

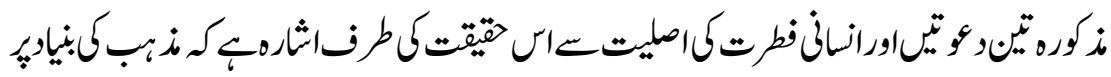

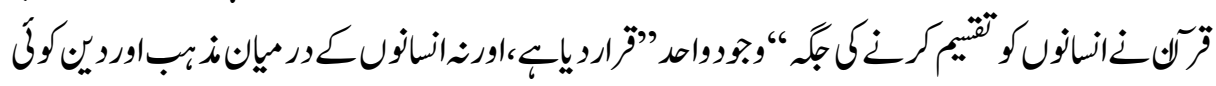

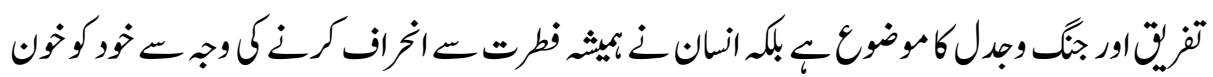

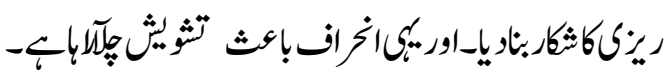

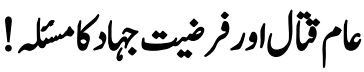

كُتب عليكم القتال وهو كرهُ لكم وعسى أن تكرهوا شيئًا وهوخيرلكم وعسى أن تحبوا شيئًا

$$
\text { وهو شرُ لكم والله يعلم وأنتم لا تعلمون } 43
$$

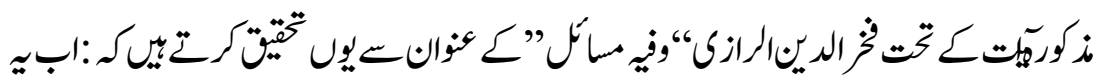

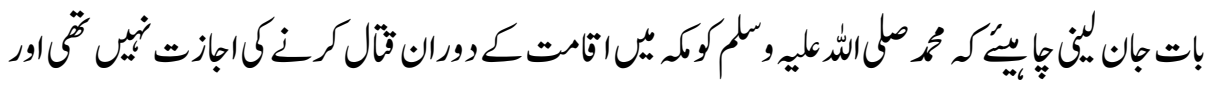

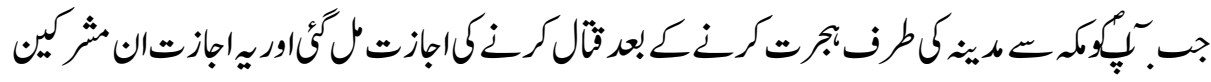

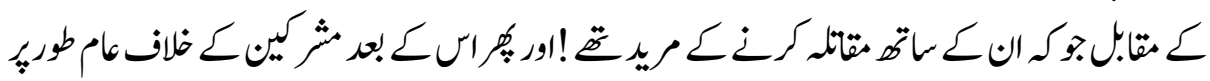

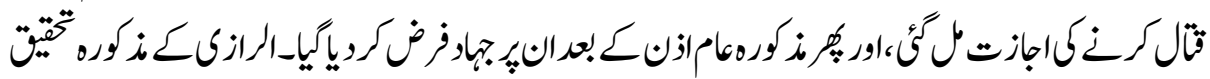

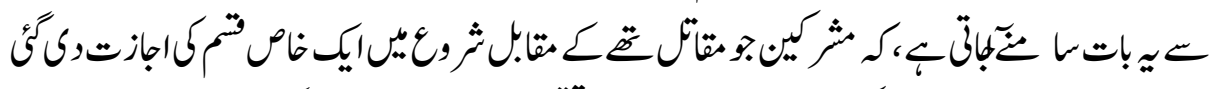

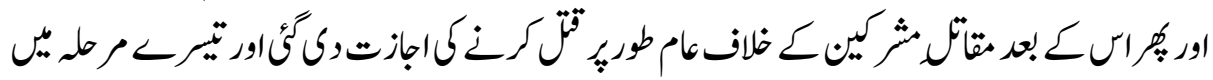
نورهازلن كوبها.

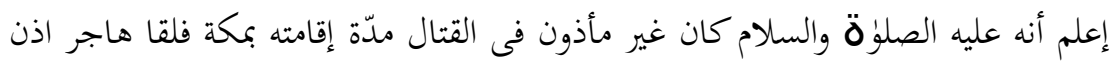

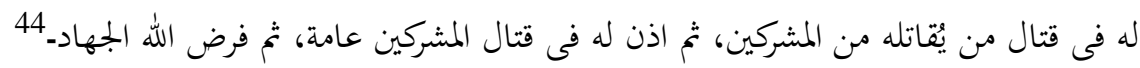

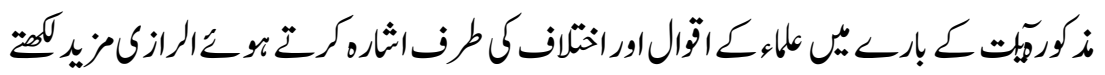

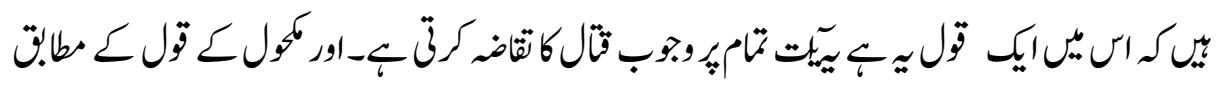
-

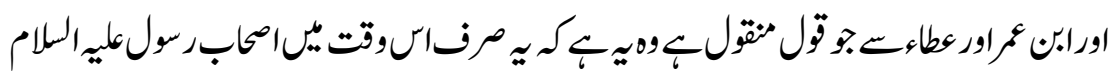

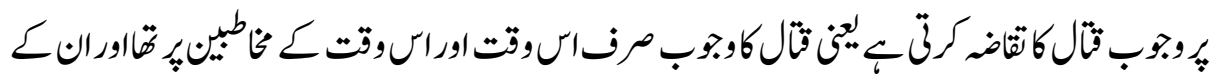
لـُ بجت قُقـ ونقل عن ابن عمرو عطاء :أن هذه الآية تقتضى وُجوب القتال على اصحاب

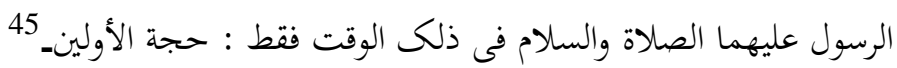




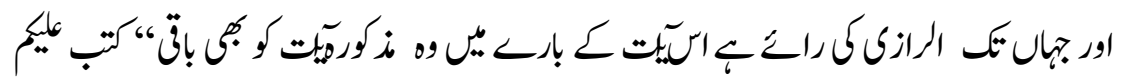

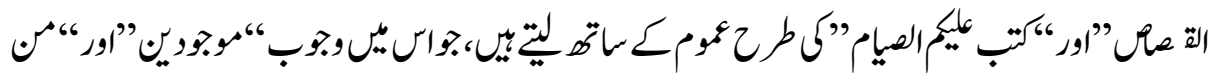

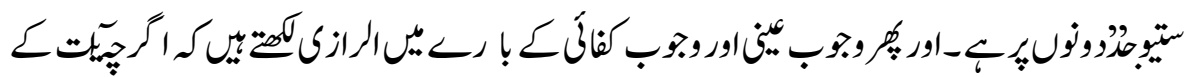

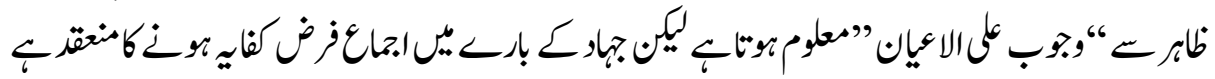

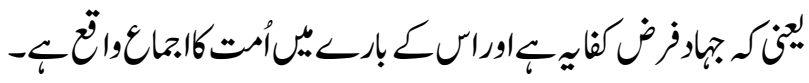

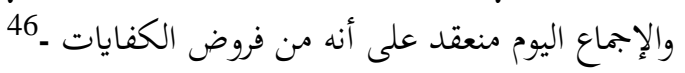

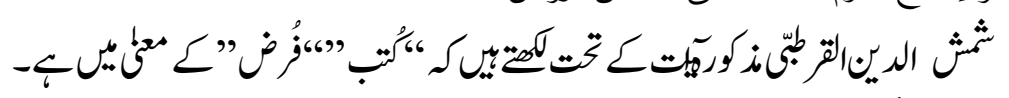

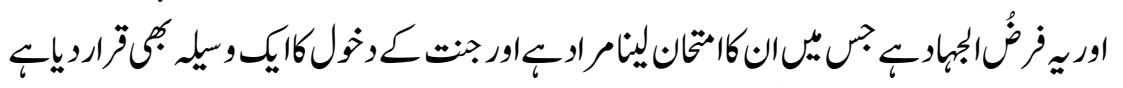

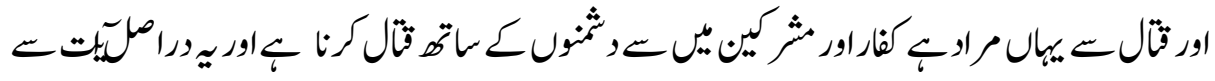

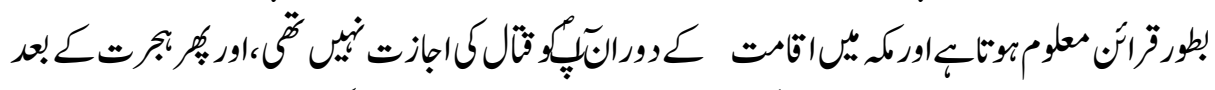

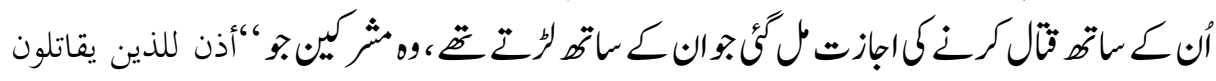

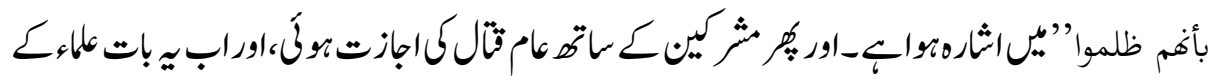

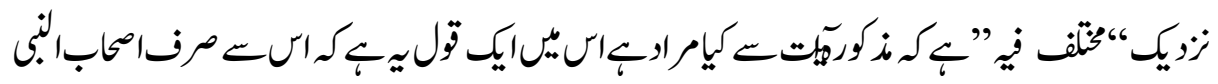

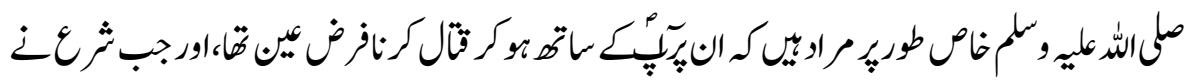

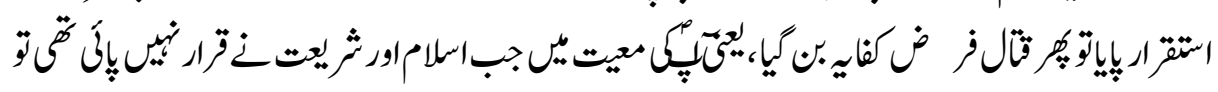

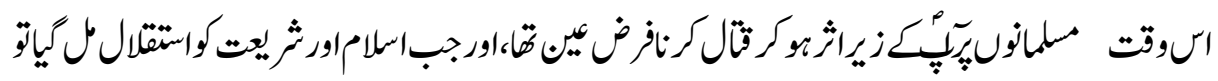

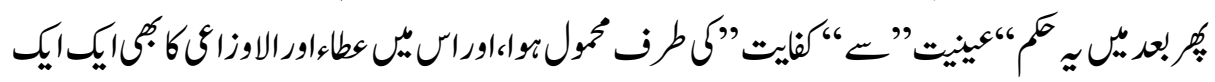

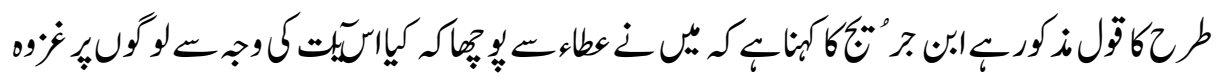

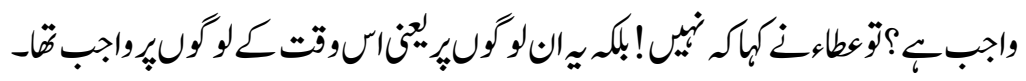

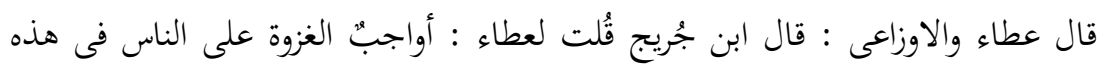

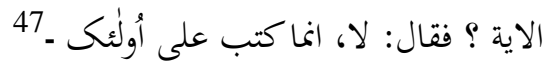

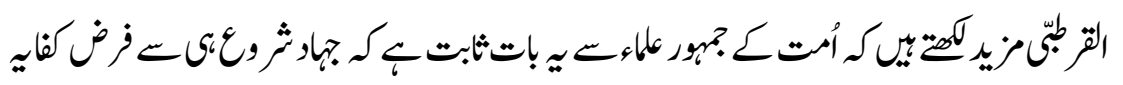

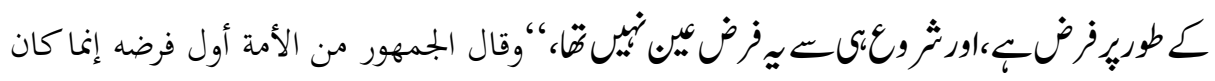
الكفاية دون تعيين ,48

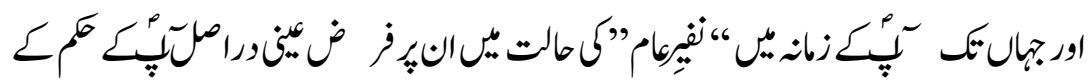




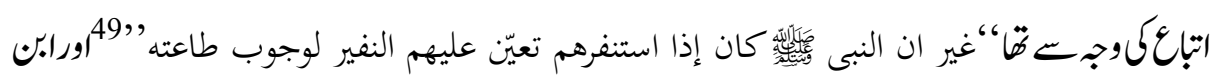

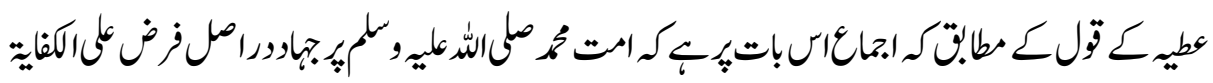

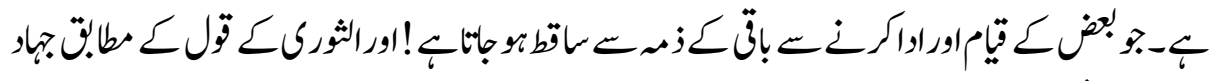

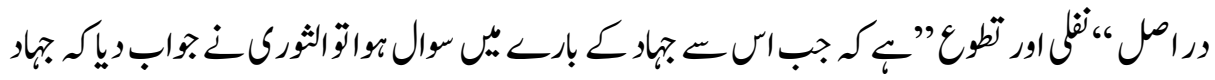

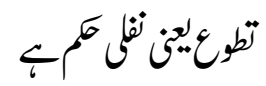

وذكر المهاونى وغيره عن الثورى أنه قال: الجهاد تطوعٌ ـ50

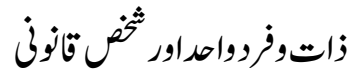

“'يسئلونك عن الانفال قل الانفال لله والرسول فاتقوا الله واصلحوا ذات بينكم

واطيعو الله ورسوله إن كنتم مؤمنين "( )

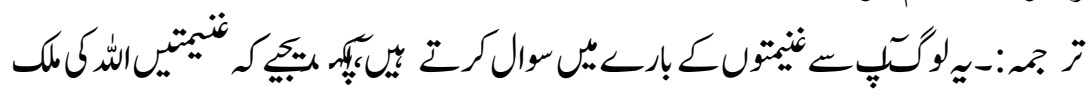

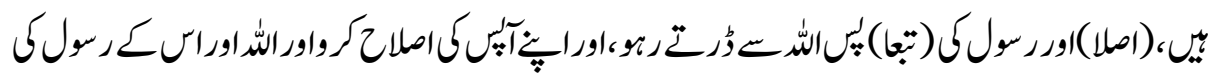

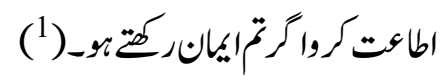

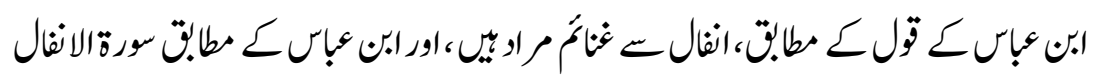

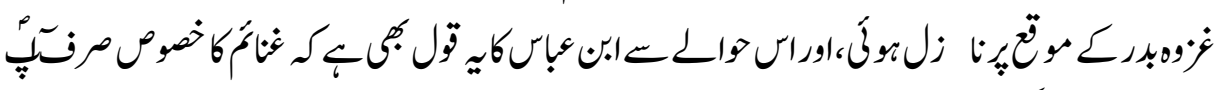

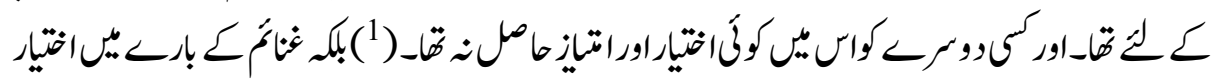

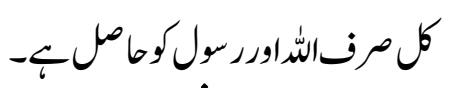

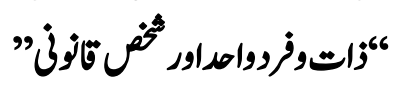

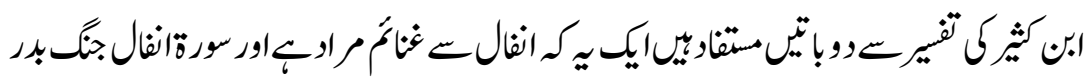

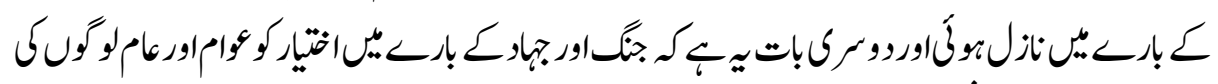

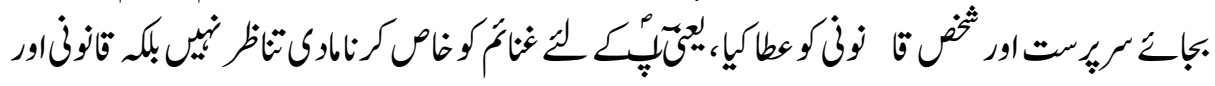

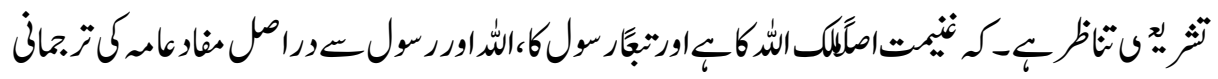

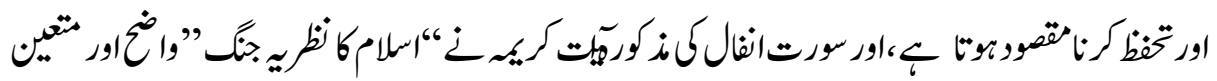

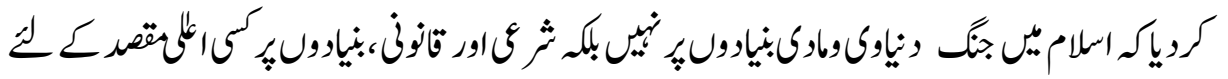

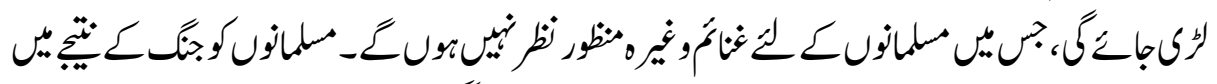

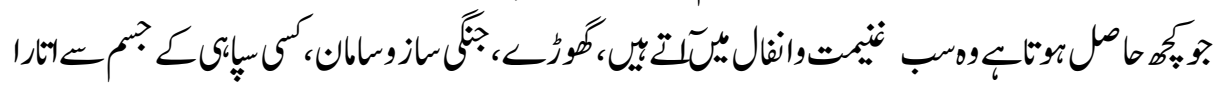




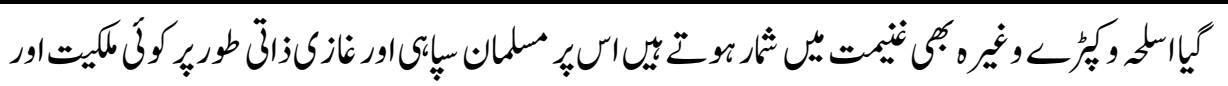

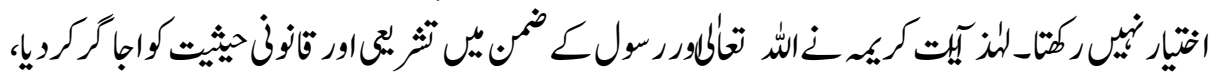

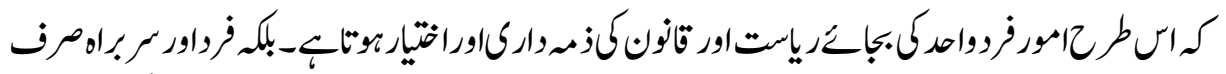

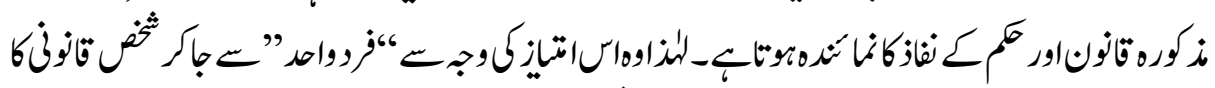

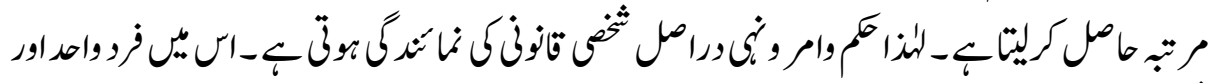

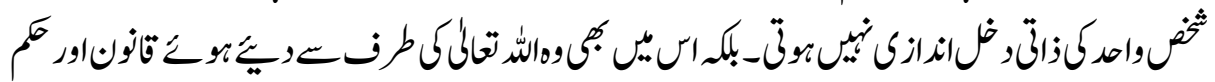

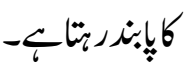

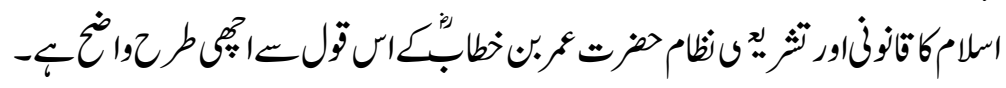

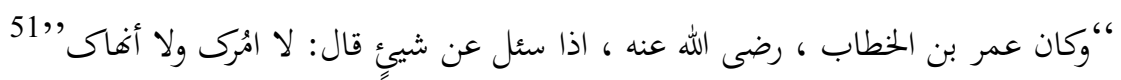

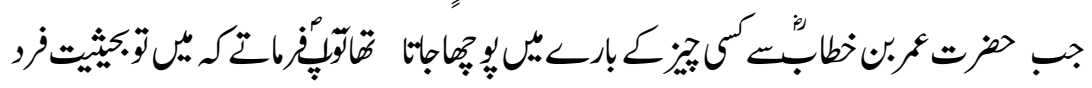

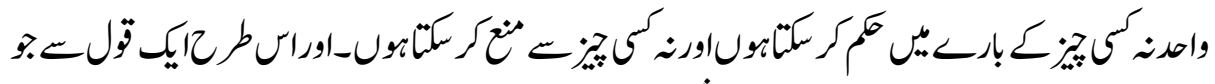

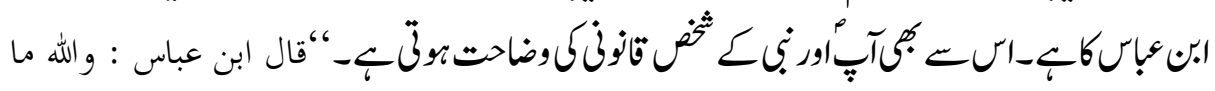
بعث الله نبيه

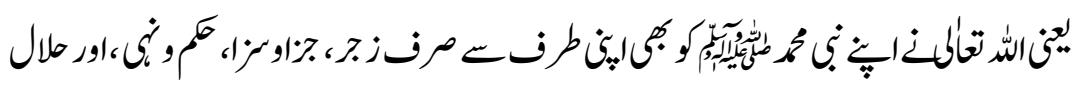

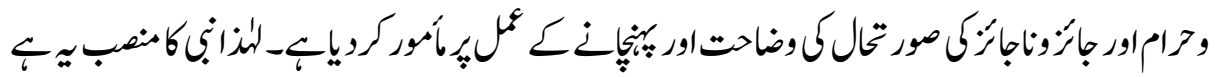

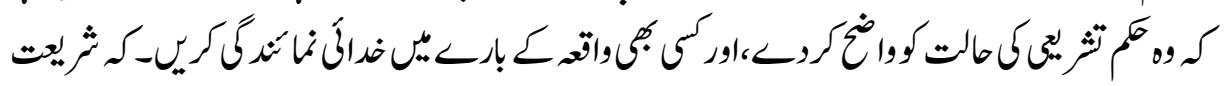

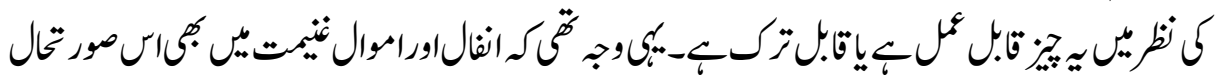

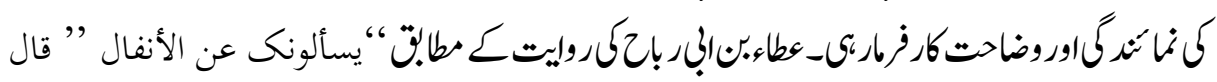

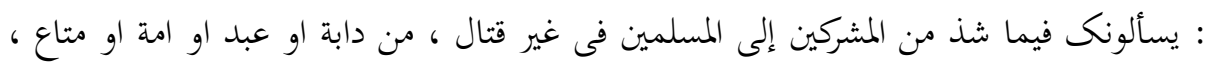

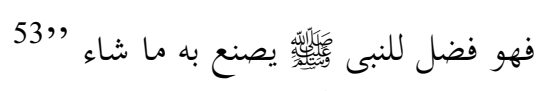

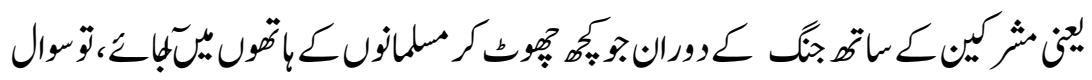

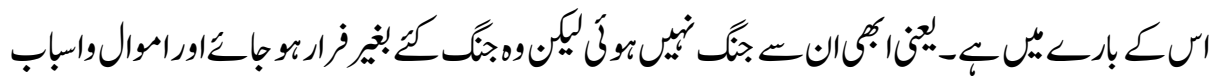

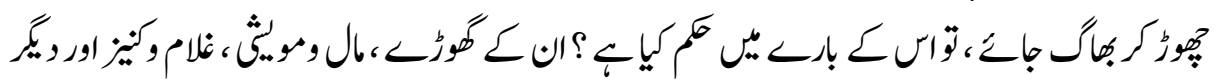

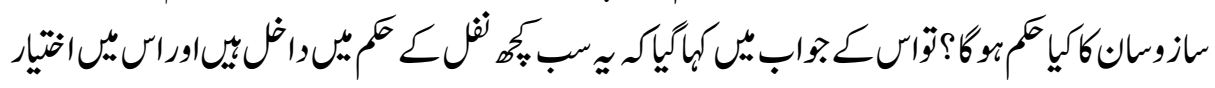




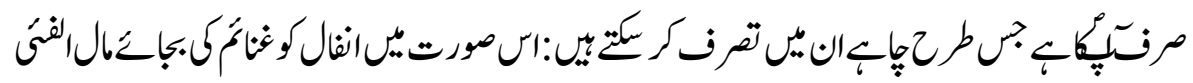

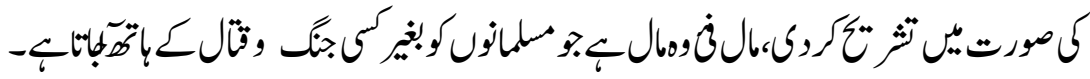

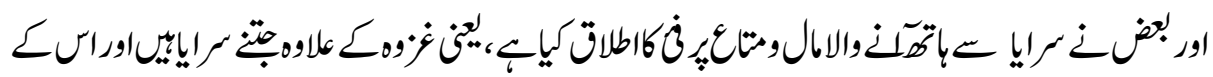

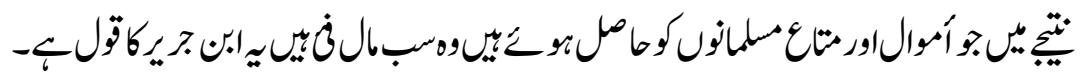

$$
\text { “'وقال آخرون : هى انفال السرايا’ }
$$

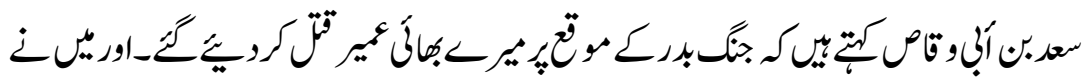

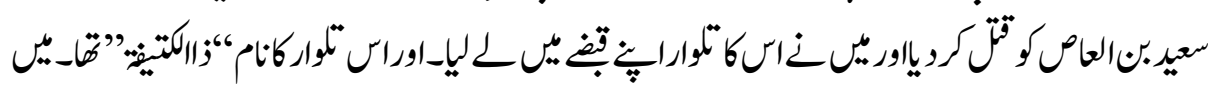

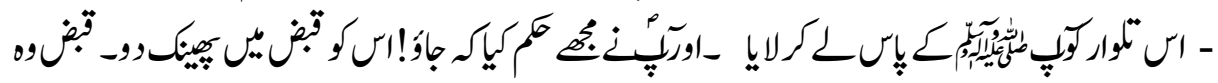

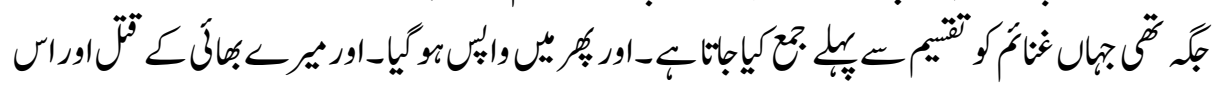

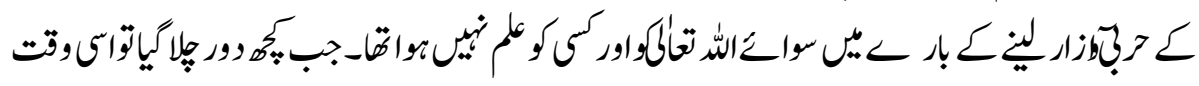

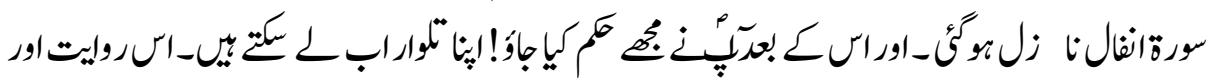

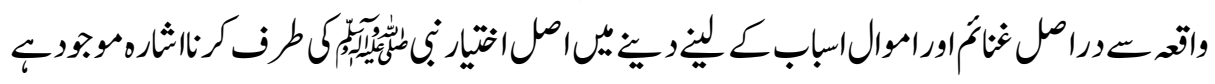

$$
\text { “'اذهب فاطرحه فى القبضِ "55 }
$$

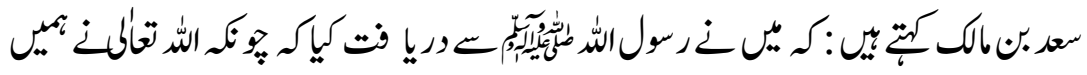

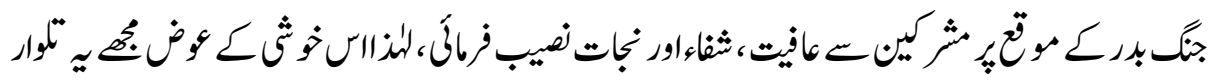

عنايتخراك

$$
\text { “66" كنب لى هذا السيف }
$$

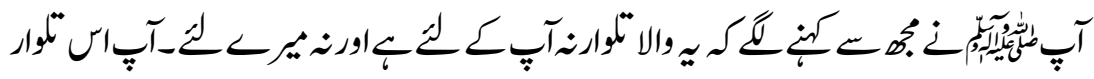

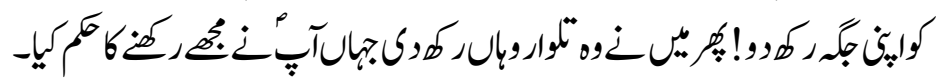

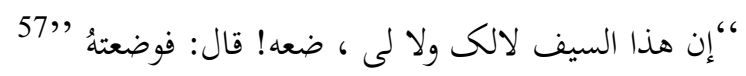

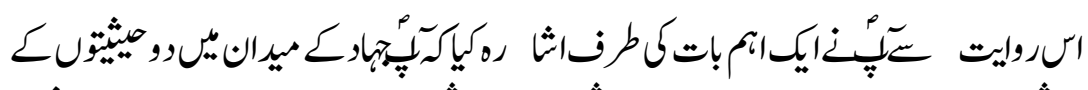

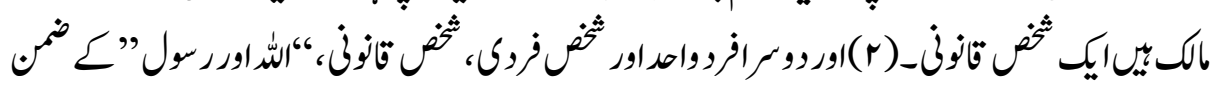

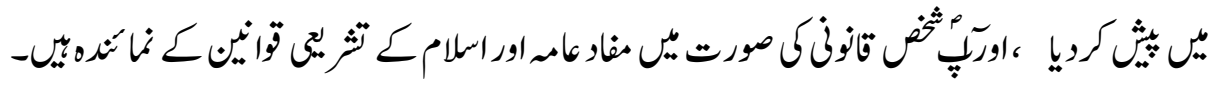




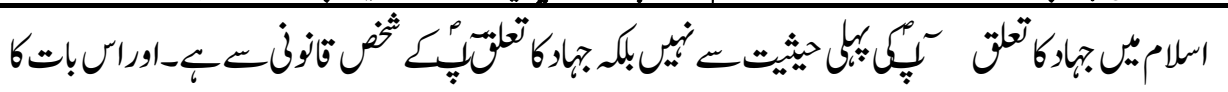

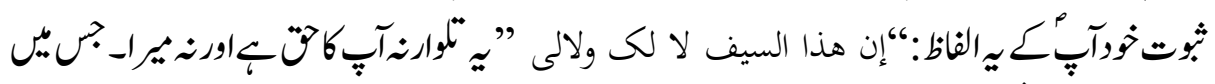

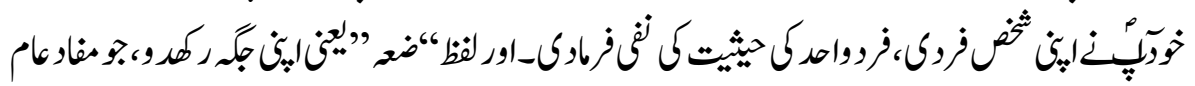

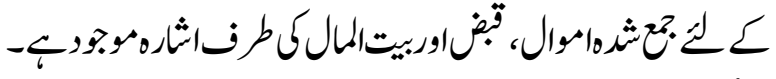

$$
\begin{aligned}
& \text { ن. }
\end{aligned}
$$

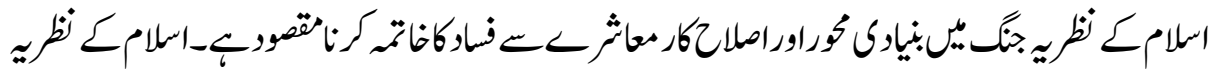

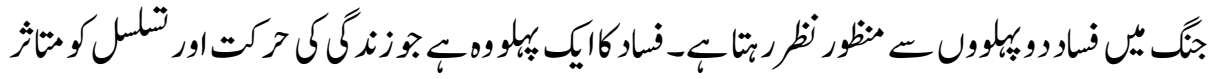

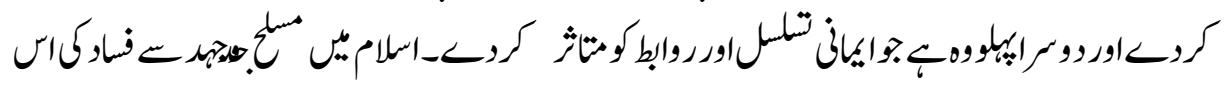

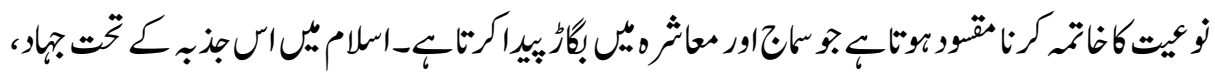

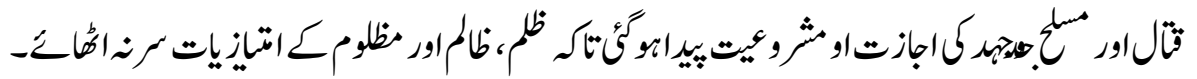

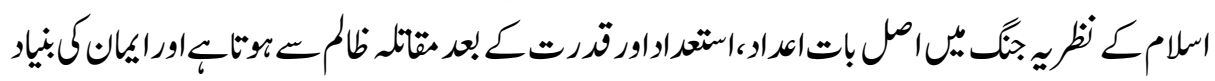

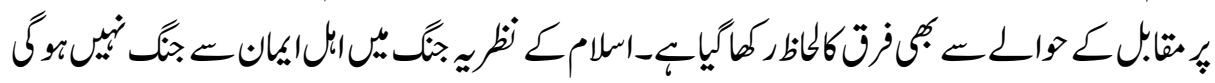

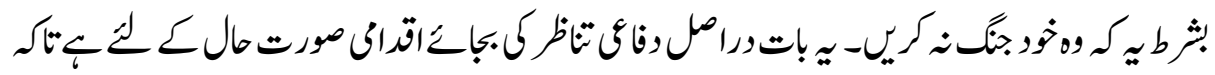

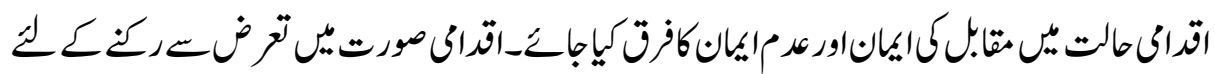

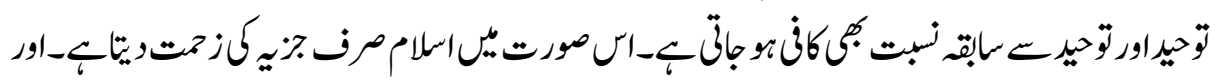

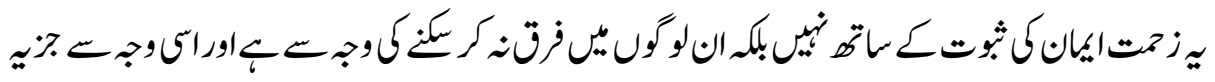

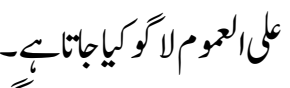

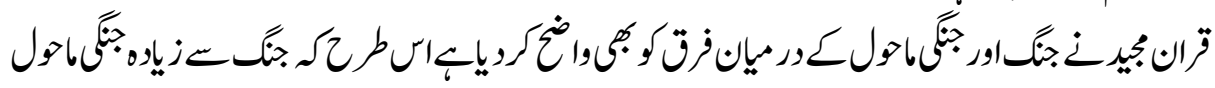

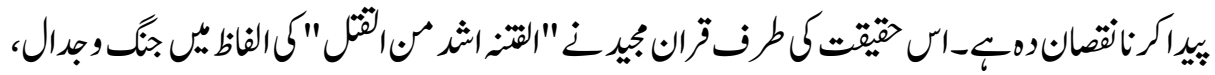

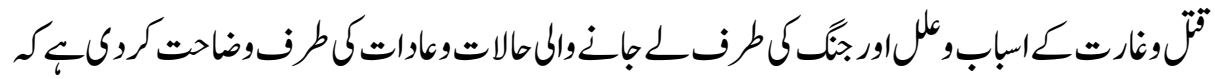

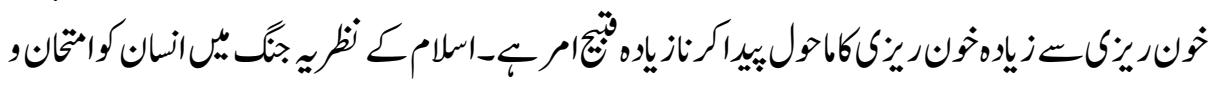

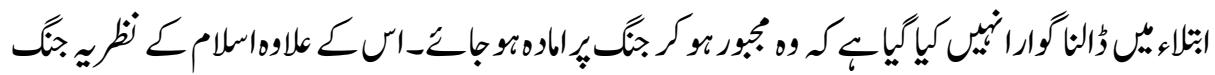

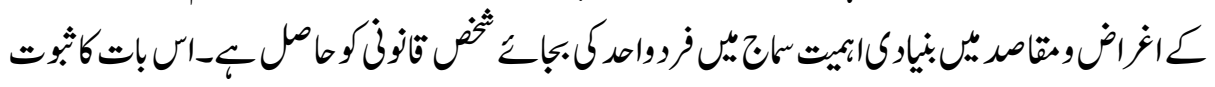

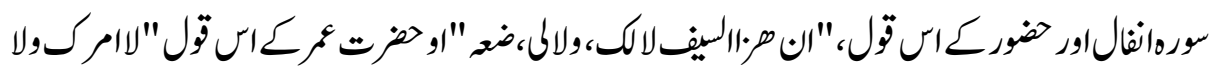




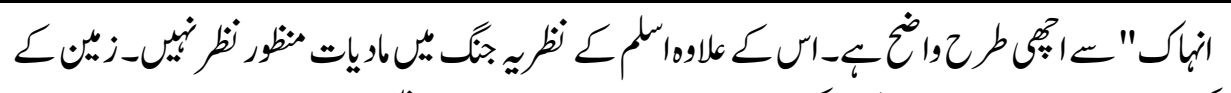

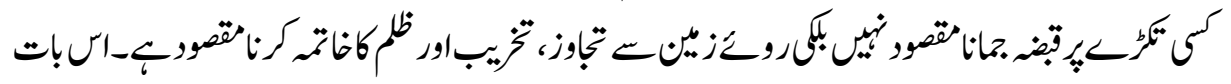

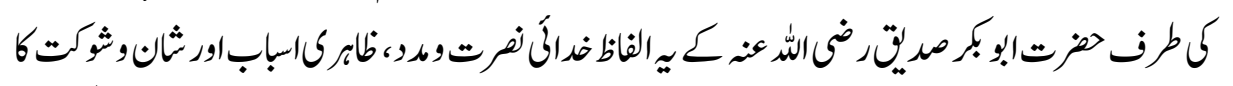

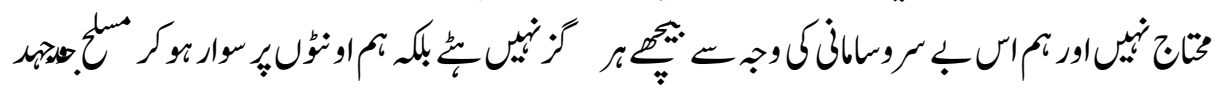

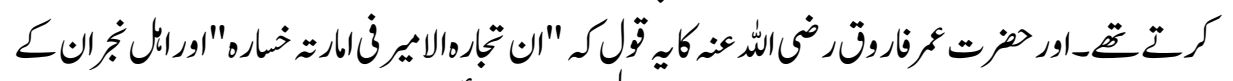

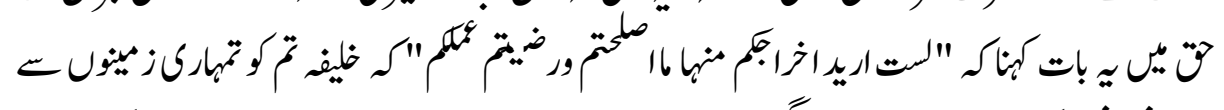

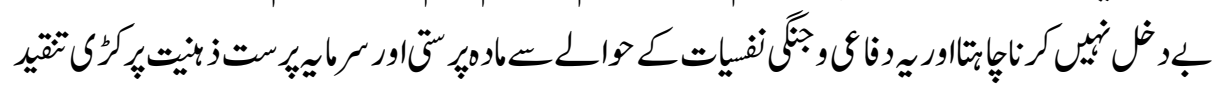
$-\frac{5}{6}$

\section{أحزات}

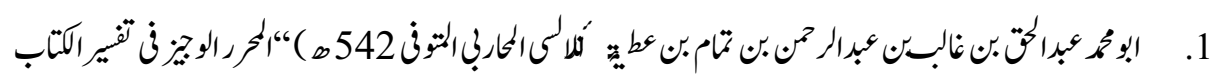

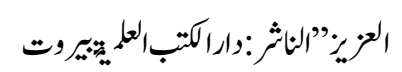

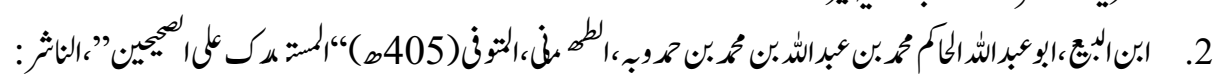

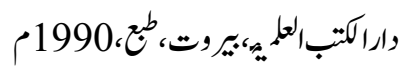

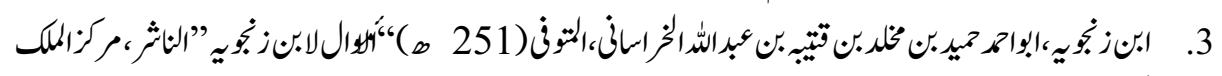

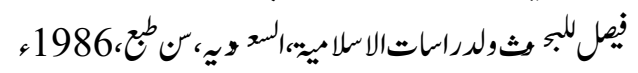

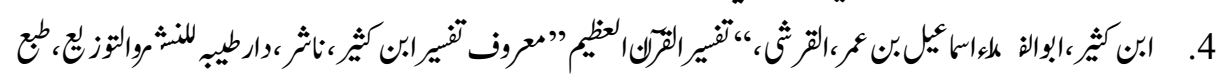
ثانيم 1999م

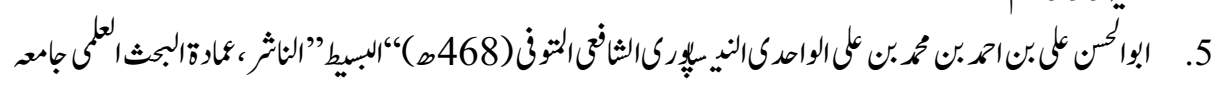

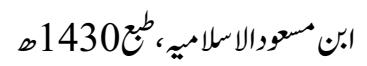

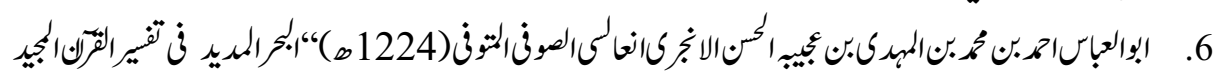

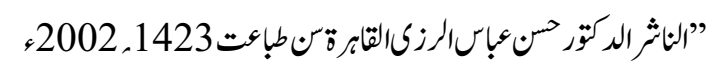

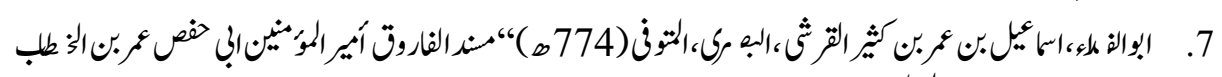

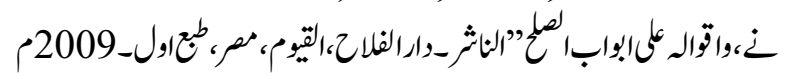

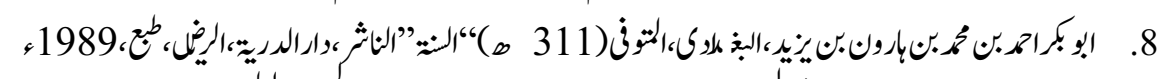

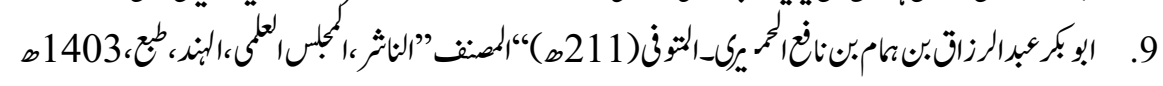




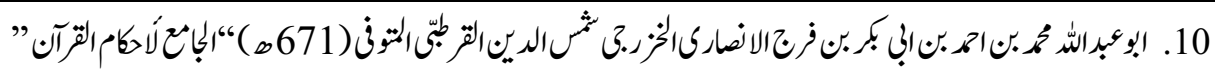

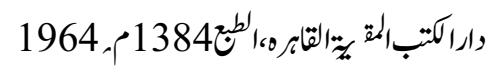

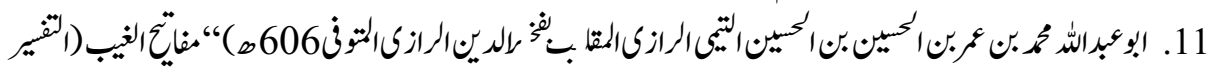

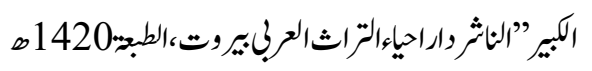

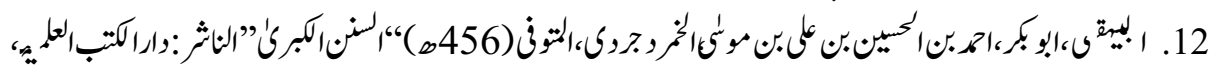

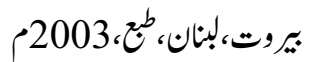

$$
\begin{aligned}
& \text { 13. تنير ابن عطي: 1250 }
\end{aligned}
$$

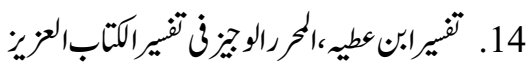

$$
\begin{aligned}
& \text { 15. تنيرالبيس }
\end{aligned}
$$

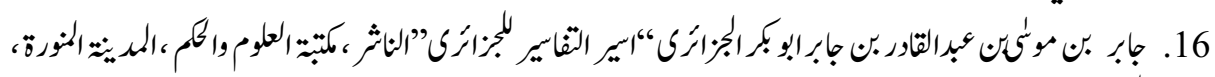

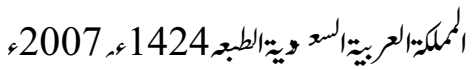

$$
\begin{aligned}
& \text { 17. الخوار (تنيراشثراوى) }
\end{aligned}
$$

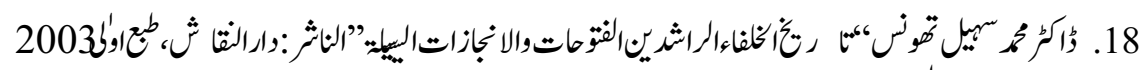

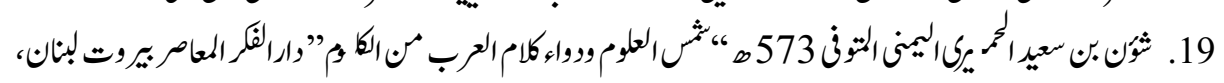

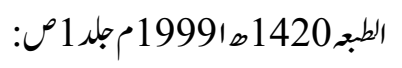

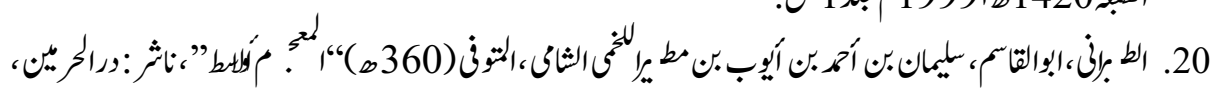

$$
\text { قإمه، مر }
$$

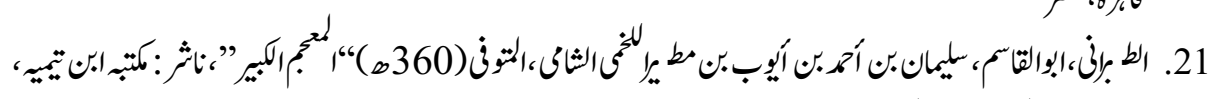

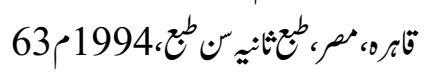

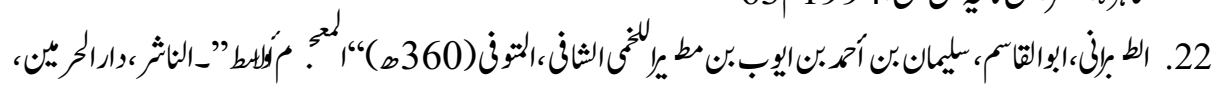

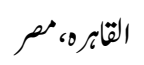

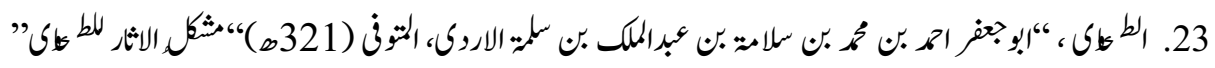

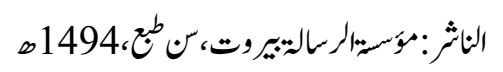

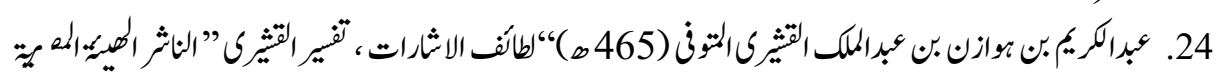

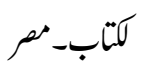

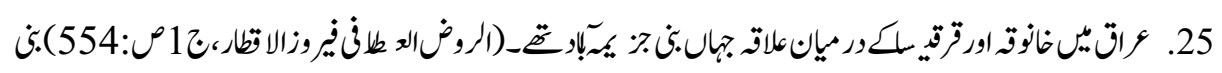

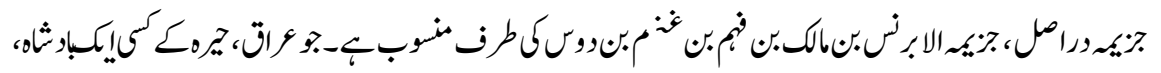

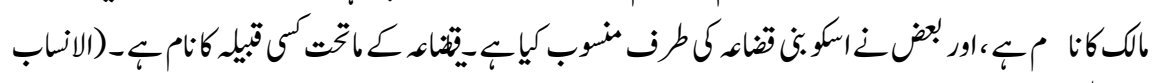

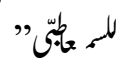




\section{References}

1. Muhammad Motawalli al Shua'rawi, al Khawatir, Akhbar al yom, 1997 v 16, pp.98 38

2. Ibdi, pp. 9838

3. Ibid

4. Ibid

5. Ibid

6. Al Hajj:39

7. Moalana Abu al Kalam Azar, Tarjuman al Quran, Sheikh Ghulam Ali and sons, Lahore,

8. Ibid, pp. 546

9. Abu al Hasan bin Ahmad bin Ali al Wahidi,, al Basit, Jamia'a Ibn al Masood al Islamia, 1430h, v15, pp. 423

10. Ibid, v10, pp. 424

11. Ibid

12. Jabir bin Mosa bin Abdul Qadir bin Jabir Abubakar, Asir al Tafseer lil Jazairi, maktab al Uloom wa al Hikam, al Madina al Munnawara, KSA, 2007, v3, pp. 479

13. Abu Muhammad Abdul Haq bun Ghalib bin abdul Rehman, al muharrar al wajir fi tafseer al kitab al azir, darul kutub al ilmia, Beirut, v4, pp. 124

14. Muhammad Motawalli al Shua'rawi, al Khawatir, Akhbar al yom, 1997 v 16, pp.9838

15. Abu al Abbas Ahmad bin Muhammad, a bahar al mudid fi tafseer al Quran al majid, Cairo, 2002, v3, pp. 537

16. Al bahar al madid fi tafseer al Quran al majid, ve, pp. 537

17. Al bahar al madid fi tafseer al Quran al majid, ve, pp. 536

18. Ibid 
19. Al Wahidi,Al tafseer al basit, v15, p 427

20. Al khawatir, tafseer al shoa'ravi, v16, pp. 9837

21. Abu Abdullah bin Muhammad, maftih al ghaib, dar ihya al turath al Arabi, Beirut, 1420h, v23, p 228

22. Ibid,

23. Ibid

24. Ibid

25. Al Hajj: 40

26. Ibid

27. Ibid

28. Ibid

29. ibid

30. ibid

31. ibid

32. ibid

33. ibid

34. Al khawatir, tafseer al shoa'ravi, v16, pp. 9837

35. Al khawatir, tafseer al shoa'ravi, v16, pp. 9837

36. Abdul Karim bin hawazan, lataif al isharat, al hiyatul misria lil kitab, Egypt, v2, pp. 548

37. Ibid

38. Ibid

39. Al Namal:52

40. Al Teen:1-4

41. Tarjumanul Quran, v3, p 184

42. Tarjumanul Quran, v3, p 186

43. Al Baqara:216

44. Mafatih al ghaib, v6, p 384

45. Mafatih al ghaib, v6, p 384

46. Mafatih al ghaib, v6, p 384

47. Abu Abdullah Muhammad bin Ahmad, al Jamia' al ahkal al Quran, darul kutub al muqaria, Cairo, 1964, v3, pp. 38

48. Tafseer al Qurtabi, v3, pp. 38

49. Ibid

50. Ibid

51. Ibn e Kathir, tafseer ibn e kathir, dar tayyiba lil nashar wa al tawzia', 1999,v4, pp. 6

52. Ibid

53. Ibid

54. Ibid 
55. Ibid

56. Ibid, v4, pp. 7

57. Ibid 